IFN Working Paper No. 804, 2009

\title{
Entrepreneurship and Public Policy
}

Magnus Henrekson and Mikael Stenkula 


\title{
Entrepreneurship and public policy*
}

\author{
Magnus Henrekson ${ }^{\ddagger}$ and Mikael Stenkula
}

May 19, 2010

\begin{abstract}
Public policy is currently shifting from SME policy towards entrepreneurship policy, which supports entrepreneurship without directing attention to quantitative goals and specific firms or employment groups. The institutional framework set by public policy affects the prevalence and performance of both productive entrepreneurship and so-called high-impact entrepreneurship in turn. Although varying contexts and economic systems make prescribing a general panacea impossible, a number of relevant policy areas are identified and analyzed. Independent of environment, productive entrepreneurship should be rewarded and unproductive entrepreneurship should be discouraged. Successful ventures must also have the incentive to continue renewing themselves just as it must be easy to start and expand a business. In particular, we analyze regulatory entry and growth barriers, labor market regulation, liquidity constraints and tax policy at length.
\end{abstract}

Keywords: Entrepreneurship; Gazelles; High-growth firms; High-impact entrepreneurship; Innovation; Institutions; Product market regulations; Property rights; Self-employment; Tax policy.

JEL Codes: L53; L25; L26; M13; O31.

Corresponding author

Research Institute of Industrial Economics (IFN)

P.O. Box 55665

SE-102 15 Stockholm

Phone: +46-8-665 4500

Fax: +46-8-665 4599

e-mail: Magnus.Henrekson@ifn.se

e-mail: Mikael.Stenkula@ifn.se

\footnotetext{
* This is a draft chapter for the new edition of Handbook of Entrepreneurship Research (New York: Springer), edited by Zoltan J. Acs and David B. Audretsch. We are grateful for useful comments and suggestions from Robin Douhan and Linda Nyberg. Financial support from the Gustaf Douglas Research Program on Entrepreneurship at IFN, from the Jan Wallander and Tom Hedelius Research Foundation and from Catarina and Sven Hagströmers Stiftelse is gratefully acknowledged.
} 


\section{Introduction}

After having been absent from mainstream policy discussion since the Great Depression, entrepreneurship was revived in the 1980s in research and policy circles alike. Spurred by David Birch's influential 1979 study, research documenting the important role of new and small firms for job generation and innovative activity began appearing. Policy making in wealthy countries soon followed in its wake. People still believed that small and new firms needed policy protection and support relative to large firms due to size-inherent cost disadvantages. Moreover, it was also thought that market failure emanating from three types of positive externalities-namely network, knowledge and learning externalities ${ }^{1}$ —necessitated corrective policy measures.

As a result, policy discussions and policymaking became focused on small firms and the incentive to become self-employed. ${ }^{2}$ Small business policy or SME policy became selective, typically driven by government agencies with a mandate to assist specific types of firms, industries, or groups of people (unemployed, women, certain ethnic groups). Policy's role was to "ensure that small firms can compete in the marketplace and that they are not prejudiced because of their small size, relative to large firms."3 Given this role, policy was evaluated using quantitative measures such as changes in the rate of self-employment, the number of start-ups, and other similar indicators.

Yet new evidence indicates that a small share of all firms, sometimes called gazelles, generate most of new net jobs. ${ }^{4}$ Acs (2009) shows that since the mid-1990s, these so-called high-impact firms have represented a tiny share of US companies (2-4 percent).

These developments have in turn influenced policy discussions. Rather than targeting small firms to compensate for their inherent disadvantages, policy has begun to shift its focus towards providing a framework for fostering a dynamic economy.

\footnotetext{
${ }^{1}$ Audretsch et al. (2007).

${ }^{2}$ See, e.g., Storey (2003), and Cumming and MacIntosh (2006).

${ }^{3}$ Lundström and Stevenson (2005, p. 37).

${ }^{4}$ See Henrekson and Johansson (2010) for a survey of the evidence.
} 
What bundle of policies ensures that people can start new ventures, develop these ventures into high-impact firms, and expand existing ventures to their full potential ${ }^{5}$

This chapter identifies the most important policy areas and measures likely to create a favorable environment for entrepreneurship, notably high-impact firms. As entrepreneurship policies do not target existing firms, our discussion will keep a systemic focus. Rather than discussing why entrepreneurship is important, we will address how public policy can stimulate entrepreneurial activity, with emphasis on productive entrepreneurship in high-impact firms.

The chapter is organized as follows. Sections 2 and 3 give a background to the following sections and discuss the differences between self-employment and entrepreneurship, and the differences between SME policy and entrepreneurship policy. Section 4 constitutes the bulk of the chapter, and discusses how an entrepreneurial economy can be promoted. It contains four subsections classified according to Baumol et al.'s (2007) four key tenets for the support of an entrepreneurial economy: Ease of starting and expanding a business, rewards for productive entrepreneurship, disincentives for unproductive entrepreneurship, and incentives to keep the winners on their toes. Section 5 concludes.

\section{Self-employment vs. entrepreneurship}

The meaning of entrepreneurship requires clarification, as does the distinction between self-employment (or small and medium sized enterprises, SMEs) and entrepreneurship. The terms entrepreneur and entrepreneurship lack an accepted definition, and are commonly used vaguely and inappropriately. For instance, the terms self-employment and entrepreneurship are often used interchangeably in empirical work.

Two aspects of entrepreneurship deserve special attention. First, entrepreneurship stems from individuals and organizations - be they new, old, large or small— that actively renew and reshape the economy. Second, entrepreneurship is a

\footnotetext{
${ }^{5}$ Hoffmann (2007, p. 140). This does not preclude that an entrepreneurial venture is sold to an incumbent fairly quickly. The full potential of a business idea will more likely be realized if it is sold to an established business with the requisite know how and financial strength (Norbäck and Persson 2009).
} 
function, pursued by specific individuals who decide whether and to what extent they supply this function.

The above distinctions underlie why self-employment or SMEs cannot be equated with entrepreneurship, and why they constitute a poor proxy in empirical work. First, in many cases, becoming self-employed is a second-best response to unfavorable institutions, and has thus nothing to do with entrepreneurial activity. Second, employees without an ownership stake can be entrepreneurial within an existing (large) company, although this seldom occurs unless compensation contracts provide the right incentives. Hence, self-employment is neither a necessary nor a sufficient condition to be regarded as an entrepreneur. ${ }^{6}$

The literature often distinguishes opportunity entrepreneurship — starting a business to take advantage of an entrepreneurial opportunity-from necessity entrepreneurship — starting a business because other employment options are either absent or unsatisfactory. ${ }^{7}$ Regarding necessity entrepreneurship as entrepreneurship is questionable indeed, although it may become (opportunity) entrepreneurship at a later stage.

Another distinction involves innovative and imitative entrepreneurship; innovative entrepreneurs introduce innovations in the economy (such as new products, new techniques and new organizational forms) whereas imitative entrepreneurs diffuse these innovations throughout the economy. ${ }^{8}$ Even if imitative entrepreneurship should not be regarded as entrepreneurship by definition, purely imitative entrepreneurs seldom exist in reality as they often modify or improve the innovation (e.g., adjust the innovation to a new market or a new customer group).

Productive, unproductive, and destructive entrepreneurship are also distinctive. The self-serving entrepreneur will pursue those entrepreneurial activities expected to generate the largest private return. ${ }^{9}$ A highly profitable venture for the individual

\footnotetext{
${ }^{6}$ See Iversen et al. (2008) and Henrekson (2007) for a further discussion.

${ }^{7}$ Reynolds et al. (2002). Sometimes the terms "pull" and "push" effects are used instead to distinguish whether individuals start ventures due to their lack of better alternatives or to exploit entrepreneurial opportunities.

${ }^{8}$ See, e.g., Baumol et al. (2007).

${ }^{9}$ This maximization behavior does not necessarily imply narrow selfishness. The entrepreneur could care about the welfare of kin and friends, or even about the welfare of the general public. It suffices that the business decisions are decoupled from such considerations. The entrepreneur maximizes profits
} 
entrepreneur may, however, have a zero or negative social rate of return. Depending on the social outcome, an entrepreneurial activity can be classified as productive (social gains), unproductive (zero social gains) or destructive (social losses). ${ }^{10}$

Finally, it is crucial to stress the importance of so-called high-impact entrepreneurship (HIE). High-impact entrepreneurial activities commercialize key innovations or create disruptive breakthroughs, extract substantial entrepreneurial rents, spur growth (in both the firm and the economy) and employment, and shift the production possibility frontier outwards. In short, HIE significantly influences the economy. HIE activity occurs within so-called high-impact firms. Entrepreneurial firms with an exceptional growth trajectory are sometimes termed high-growth firms (HGFs) or "gazelles." Yet a typical start-up is not characterized by HIE; and highimpact entrepreneurship is not necessarily performed within new (or small) companies. $^{11}$

\section{Entrepreneurship policy vs. small business policy}

Stimulating entrepreneurship and small business activity sits high on the agenda of developed and developing countries alike. This is striking given that large companies commanded attention during much of the post-war period. Recently, however, globalization has spurred focus on entrepreneurship. Increased product and market integration have thwarted efforts to protect incumbents, allowing successful entrepreneurs to extract higher profits. This, in turn, increases the lobbying power of potential entrepreneurs relative to incumbent firms. ${ }^{12}$ Public discourse often regards entrepreneurship and small businesses as an economic panacea. While this view is exaggerated, it is fair to claim that productive entrepreneurship plays a key role in economic development.

selfishly, but no constraint is put on the use of these profits. These may or may not be spent with altruistic considerations in mind.

${ }^{10}$ Baumol (1990), and Murphy et al. (1991).

${ }^{11}$ See Acs (2008) for an in-depth discussion of HIE. Acs claims that HIE should be an activity focused on (homogeneous) mass production within the product market sector. However, we find it unnecessary to restrict the concept of HIE to specific business activities and/or strategies.

${ }^{12}$ See Douhan et al. (2009). 
The government can wield public policy_namely, the use of tools by policymakers to influence society in a politically desired manner ${ }^{13}$ - to stimulate the economy. Entrepreneurship can be encouraged by efforts ranging from specific targeted support, such as technology assistance to small firms, to general macro policies to maintain a stable economic environment.

It should be noted, however, that SME policy does not parallel entrepreneurship policy. ${ }^{14}$ SME policy involves policies directed specifically at supporting SMEs (including self-employment), and can be justified on several grounds. It can be used to spur perceived positive macroeconomic side-effects — such as increased employment, growth or innovation output—or to compensate for perceived negative microeconomic side-effects—such as scale-economies or other cost and information disadvantages—associated with the SME sector. ${ }^{15}$ This policy approach commonly involves the creation of specific government agencies that support SMEs in a range of small firm support programs and subsidies.

Entrepreneurship policy is a much broader concept. Its aim is not to stimulate firms but to support an economic system that encourages socially productive entrepreneurial activity by individuals acting independent of business form. SME policy influences quantitative aspects, such as the number of self-employed and small or new firms, and the size distribution of firms. This rests on the premise that more SMEs and self-employment is always better, since it increases entrepreneurship in the economy. Yet most definitions of entrepreneurship find no truth in this assertion. Pervasive small-scale businesses or self-employment would not benefit a country's economy. ${ }^{16}$ Moreover, searching for an "optimal" level of self-employment and trying to steer the economy towards this level would be foolish as well. Such a level cannot be determined; even if it did exist, it would fluctuate over time and differ across regions and industries. It is not feasible to fine-tune a modern market economy in this manner.

\footnotetext{
${ }^{13}$ Hart (2003).

${ }^{14}$ Lundström and Stevenson (2002).

${ }^{15}$ See, e.g., Storey (2003) or van Stel (2007). Audretsch et al. (2007) mention network, knowledge, and learning externalities as three examples of market failures that work against SMEs in the economy. Rodrik (2007) points to information and coordination externalities as one basis for government intervention.

${ }^{16}$ Audretsch et al. (2002, p. 45).
} 
As it is difficult—if not impossible — for policy makers to a priori determine who will be an entrepreneur, measures directed at a specific group or a specific form of business are largely misdirected. ${ }^{17}$

Public policy should not try to influence the "natural" evolution of firm size, growth, or form through targeted subsidies or tax breaks. Market forces and profit motive alone should govern the evolution of firms. ${ }^{18}$ Unless a substantial market failure that can be rectified through public policy exists, targeted programs should be looked upon with skepticism. A system replete with special treats and regulations for select categories results in a complex system with detailed rules, exceptions, and exceptions to the exceptions, which in the end impairs all activity due to increased administration and information costs. These costs are almost always more burdensome for SMEs because of the existence of a sizable fixed cost component. ${ }^{19}$ Moreover, complex systems provide opportunities for unproductive and destructive entrepreneurship.

Normally, welfare increases if the economy allows and rewards productive entrepreneurial initiatives across the board, independent of firm and individual characteristics. A well-designed entrepreneurship policy facilitates productive entrepreneurial activities and enables the creation and commercialization of valuable knowledge. ${ }^{20}$ Whether this implies a high or low rate of self-employment or SMEs is largely irrelevant. Instead of focusing on quantitative aspects of entrepreneurship, entrepreneurship policy should focus more on the qualitative aspects. Empirical evidence suggests that an economy that fosters (a few) high-impact entrepreneurial firms and high-growth firms is superior to an economy that tries to maximize the number of SMEs or the rate of self-employment. ${ }^{21}$

\footnotetext{
${ }^{17}$ Cf. Holtz-Eakin (2000), who claims that it is virtually impossible to clearly identify entrepreneurs.

${ }^{18}$ Cf. Holtz-Eakin (2000).

${ }^{19}$ EU (2007, 2008).

${ }^{20}$ Acs and Szerb (2007, p. 112).

21 See, e.g., Shane (2008, p. 162), who states that: “[N]ew company formation per se isn't what matters; rather it's the creation of a small number of super-high-potential new companies, which among them generate almost all the economic growth and job and wealth creation that comes from having an entrepreneurial economy [...] A strategy that revolves around increasing the number of new business created every year is flawed."
} 
In many countries, public policy is currently shifting emphasis from SME policy towards entrepreneurship policy. Figure 1 depicts major distinctions between these two concepts.

Nonetheless, the entrepreneur is not the only agent important for economic progress. Successful entrepreneurs who identify and exploit new ideas - thereby creating and expanding businesses - depend on a number of complementary agents, such as skilled labor, industrialists, venture capitalists and secondary markets. It is important to keep in mind that successful entrepreneurs cannot succeed without these complementary competencies and inputs. ${ }^{22}$ Focusing on just the entrepreneur distracts from important factors necessary for an economy to prosper. Still, entrepreneurship is crucial; a lack of productive entrepreneurs cannot be fully offset by an ample supply of skilled labor or an extensive capital market.

Quantitative policy goals have the advantage of being easier to evaluate. Many studies that evaluate support programs use a quantitative measure. They may, for instance, assess whether a certain policy has boosted the number of small firms. Academics prefer quantitative variables, as they facilitate both empirical and econometric analysis. Illusive qualitative concepts like entrepreneurship, however, are more difficult to handle.

Evaluating and analyzing entrepreneurship policy is less straightforward. Be that as it may, entrepreneurship policy exists to stimulate job creation, innovation, social welfare and economic growth: lacklustre performance in these dimensions indicates a need of policy reform.

\footnotetext{
${ }^{22}$ Johansson (2010).
} 
Figure 1. SME Policy vs. Entrepreneurship Policy

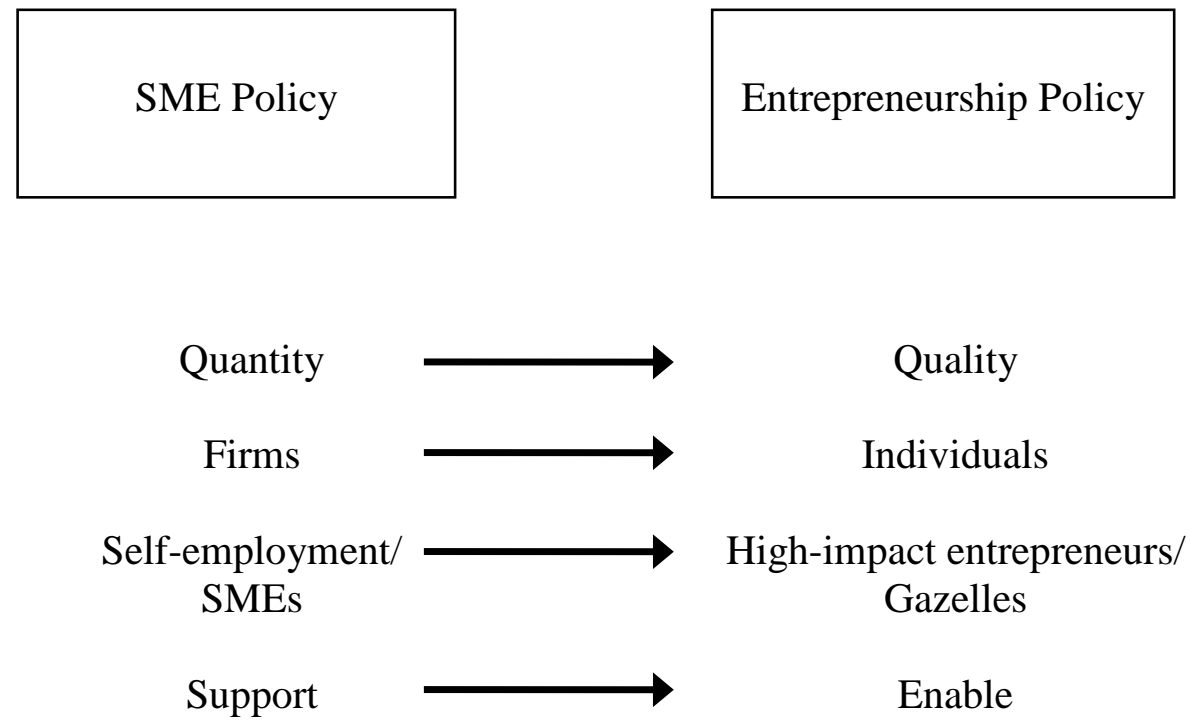

\section{Entrepreneurship policy}

The research literature identifies at least 25 factors ranging from labor market regulations to public sector size that influence the rate of entrepreneurial activity. ${ }^{23}$ Compiled systematically, public policy influences entrepreneurial activity in five different areas:

- the demand side of entrepreneurship;

- the supply side of entrepreneurship;

- the availability of resources, skills and knowledge;

- $\quad$ preferences for entrepreneurship; and

- the decision-making process of potential entrepreneurs. ${ }^{24}$

Irrespective of classification, it is tricky to evaluate the effectiveness of different policy options. As discussed earlier, measurement poses the first problem. Second, different policy measures will likely interact, with ambiguous effects-policies can be

${ }^{23}$ Lundström and Stevenson (2002).

${ }^{24}$ Audretsch et al. (2002). 
complementary, but they may also counteract each other. ${ }^{25}$ Third, policies geared towards other goals may also influence entrepreneurial activity. ${ }^{26}$ As the effect of a policy tool depends on the whole policy mix in the economy, it is virtually impossible to fully identify the factors affecting entrepreneurial activity; to quantify their respective effect is of course even more difficult.

In short, context matters. ${ }^{27}$ Political, economic, and cultural systems differ across countries, each of which has characteristics that cannot be replicated or imitated by public policies. Although using both cross-national benchmarking and best practice comparisons is worthwhile when evaluating different policy tools, doing so largely ignore the importance of context. Countries may have different binding constraints, and the importance of a particular factor may be greater in one country than in others. Therefore, ranking different policies as "best practice" may at best give rough policy guidance and at worst be quite misleading. ${ }^{28}$

No time-invariant and universal general policy prescriptions exist that can and should be used to stimulate entrepreneurial activity. As entrepreneurship research is multidisciplinary and diverse, no generally accepted theory exists. Patterns can be traced between countries using suitable empirical and econometric techniques, but one must avoid drawing strong general conclusions based on this research. Even if several studies find one aspect to be (the most) important, this factor may not be similarly relevant in other economies not covered by the study.

Time span poses an additional problem. Several studies have shown that public policy rarely influences entrepreneurial activity in the short run. ${ }^{29}$ This can stem from cultural inertia but also transaction/switching costs, which make public policy towards entrepreneurship ineffective. Depending on the political time horizon, different policies may prove optimal from different points of view. ${ }^{30}$

\footnotetext{
25 Orszag and Snower's (1998) study of the complementarity of different policies in the area of unemployment provides an interesting parallel. They show how the effectiveness of one policy depends on the implementation of other policies.

${ }^{26}$ OECD (2007).

${ }^{27}$ Cf. Boetttke and Coyne (2009, p. 144).

${ }^{28}$ Cf. Rodrik (2007), Boettke and Coyne (2009), and Lundström and Stevenson (2002).

${ }^{29}$ Acs and Szerb (2007).

${ }^{30}$ Acs and Szerb (2007) state that information, opportunity recognition, and skill development are the most important factors influencing entrepreneurial activity in the short run.
} 
Even if a country's culture can impede progress in the short run, cultural patterns are not immutable. Public policy can alter attitudes in a society over time. To the extent that norms and attitudes are culturally codified products of the reward structures in society, institutional changes are likely to affect norms and attitudes. ${ }^{31}$ Furthermore, the importance of culture may not only induce inertia but also produce a positive reinforcing feedback cycle. A more entrepreneurial culture generates a larger "demonstration effect," a process in which people are exposed to (successful) entrepreneurs and are in turn stimulated to engage in entrepreneurial activities; soon more people are being stimulated, which strengthens the entrepreneurial culture even further. ${ }^{32}$ Yet causality may run in the opposite direction. A vivid entrepreneurial culture is not a cause but rather a by-product of institutions that foster entrepreneurship. ${ }^{33}$ Culture is a proximate rather than an ultimate cause; focusing on its role in spurring entrepreneurial activity is misleading indeed.

These insights provide the backdrop for the remainder of this chapter. As context matters, we eschew a general ranking of best practice policies. Instead, we discuss a smorgasbord of factors that research has shown to be of importance.

Many perspectives can color a discussion of entrepreneurship policy; as our starting point, we take Baumol et al.'s (2007) four primary tenets underpinning an entrepreneurial economy:

- ease of starting and growing a business;

- generous rewards for productive entrepreneurial activity;

- disincentives for unproductive activity, and

- incentives to keep the winners on their toes.

All four tenets and their relevant policy tools will be discussed below. All in all, eleven public policy areas are analyzed in this chapter. Of course, the separate policy areas may influence several tenets at once; we have thus listed the policy area under the most relevant tenet in the text below. Table 1 presents a general overview of the policy areas and policy tools to be discussed.

\footnotetext{
${ }^{31}$ Bowles (1998), Baumol et al. (2007, pp. 203ff), and Smith (2003).

${ }^{32}$ Audretsch et al. (2002).

${ }^{33}$ See Boettke and Coyne $(2003,2009)$ for a further discussion.
} 
Table 1 about here

A final word of caution regarding the outcome of entrepreneurship policy is justified. Public policy has to strike a balance between different goals and different interest groups - tradeoffs are inevitable and must be dealt with. This is also true for entrepreneurship policy.

\subsection{Ease of starting and expanding a business}

Being able to start and expand a business with ease is vital in stimulating entrepreneurship. Public policy directly influences firm formation and expansion through laws and regulations—including direct prohibition— - but also does so indirectly through the social security system and labor market regulation. Public policy also stimulates entrepreneurship indirectly through measures that alleviate natural constraints, such as capital requirements.

\subsubsection{Regulatory entry and growth barriers}

Although natural entry barriers such as scale economies and capital requirements exist, government regulations can also impede new venture formation and expansion. Indeed, governments forge both direct and indirect entry barriers. Direct entry barriers refer to the act of restricting and even prohibiting entry into certain sectors of the economy (such as health care), while indirect barriers involve administrative costs and regulatory burdens imposed on new (and/or existing) firms. Expressed in another way, public policy can directly stimulate entrepreneurship by deregulating the economy, thereby increasing the opportunities for competition; alternatively, the government can indirectly stimulate entrepreneurship by easing administrative and legislative burdens, thereby allowing entrepreneurs to devote more of their time, money, and effort to productive activities. ${ }^{34}$

\section{Direct barriers}

\footnotetext{
${ }^{34}$ Storey (1994).
} 
Direct entry barriers can be justified as consumer protection against fraudulent or incompetent business owners. Few would support a system in which anybody could work as a doctor, surgeon, or psychologist; strong arguments can be made for direct entry barriers for persons lacking requisite skills or know-how. ${ }^{35}$ However, overly extensive regulations hamper productive entrepreneurship. Research indicates that occupational licensing, for example, may have gone too far, resulting in unjustified profit opportunities for license holders rather than consumer protection. Consequently, licensing may curb the rate of innovation. ${ }^{36}$

In recent decades, the governments of developed countries have deregulated product markets with the aim of increasing market contestability and providing more opportunities for private entrepreneurship within telecommunications, transportation, and financial services, for example. The scope for new high-impact entrepreneurs has thus increased dramatically.

Yet one segment of most advanced economies remains heavily regulated and even monopolized by the public sector: the provision of social services such as health care, child and elder care, and education. This is so despite that these services are primarily private goods. As demand for these services increases as a result of aging and wealthier populations, the social benefits arising from productive entrepreneurship in these areas would be substantial. ${ }^{37}$ Indeed, these industries already constitute 30 percent of GDP in the Scandinavian welfare states, and about 20 percent in the OECD. ${ }^{38}$ While several of these markets have been partially opened to private competition in recent years, many impediments still loom—private firms only produce a fraction of total output.

Government monopolization of production frustrates organizational development and productivity. Typically, local or regional governments control production and are prohibited from expanding outside their own region. As a result, efficient organizations cannot expand geographically. Consumers (e.g., patients) in the region may also be restricted to using the local provider. Such policy generates small regional production monopolies controlled by the government. Efficient producers

\footnotetext{
${ }^{35}$ OECD (2007).

${ }^{36}$ Kleiner (2006). For an early critique of occupational licensing, see Friedman (1962, chapter 9).

${ }^{37}$ The income elasticity of these services has been estimated to be as high as 1.6 (Fogel 1999).

${ }^{38}$ Adema (2001), Adema and Ladaique (2005), and Andersen (2008).
} 
cannot expand outside their local domain and inefficient public organizations continue to operate under little pressure to improve. Furthermore, government ownership decreases management interest in innovation, as they cannot reap the same benefits from these activities as private owners could (the producer is not the residual claimant). ${ }^{39}$

Hence, the public sector's de facto monopolization of many income-elastic services has excluded vast areas of the economy from entrepreneurial exploitation. Part of this problem can be rectified by substituting private commercial firm production for public sector production, even if the service is provided free (or almost free) of charge to customers. ${ }^{40}$ In addition, service producers can be permitted to offer additional services beyond what is granted through a tax-financed voucher system. This, too, would provide stronger incentives for entrepreneurs. Such a scheme would likely spur the emergence of new high-impact entrepreneurs in the health care sector.

Near-exclusive reliance on taxation for the financing of health care, child and elder care, and education becomes more problematic as real income grows, since these highly income-elastic services suffer from Baumol's Disease, i.e., their relative price tends to increase over time because they largely consist of labor intensive services with low or zero productivity growth. ${ }^{41}$ Technological breakthroughs also increase the supply of services in the health sector. When private purchasing power is restricted from these sectors, they become tax-financed "cost problems" rather than potential growth industries attracting talented entrepreneurs and other key agents and competencies.

Even if private high-impact firms are not permitted entry into areas like health care, the private sector may still be affected by activity in these sectors. The public sector buys services and products for billions of euros each year; monopolized public sector segments are and can be a major market for many private firms and entrepreneurial initiatives. SME production commonly holds just a small share in these segments, which SME policy aims at increasing. Even if SMEs do not have an inherent

\footnotetext{
${ }^{39}$ See, e.g., Shleifer (1998).

${ }^{40}$ See, e.g., Jensen and Stonecash (2005) for an overview of public sector outsourcing. Even if only part of public production is privatized, the non-privatized part may improve. Bergström and Sandström (2005) have found that school results in Swedish public schools improved due to competition from independent schools under a voucher system covering all children.

${ }^{41}$ Baumol (1993), and Jansson (2006).
} 
advantage, public procurement policies should at least be as neutral as possible in regard to large firms and SMEs. ${ }^{42}$

\section{Indirect barriers}

That extensive entry barriers deter business entry is corroborated throughout the empirical literature. ${ }^{43}$ Entrepreneurship is facilitated if it easy and inexpensive to form (or expand) a business. Hence, administrative, legislative, and regulatory burdens should be as low as possible to stimulate entrepreneurship, save for regulation necessary to ascertain product safety and assuage distributional concerns.

It is useful to distinguish between different entry barriers. The World Bank has constructed an index measuring the ease of doing business in different countries (the WBDB indicator). They use four variables: length of time, complexity of the procedures, direct cost, and minimum capital necessary to start a business. ${ }^{44}$ Research based on this dataset shows that entry barriers discourage start-ups. ${ }^{45}$ Despite that research shows that entry barriers matter, researchers disagree on which entry barriers are most important. ${ }^{46}$

Entry barriers raise both direct and indirect costs of starting a business and therefore constrain possibilities to exploit new opportunities. An entrepreneur will only found or expand a business if expected profits compensate for the costs and uncertainty associated with the project. Hence, increased regulatory and procedural costs raise the required rate of return necessary for an entrepreneurial opportunity to be exploited. ${ }^{47}$ High costs deter potential entrepreneurs. ${ }^{48}$

Regulatory burdens do not only impede firm start-ups, but also the expansion of existing small firms. ${ }^{49}$ Entrepreneurial firms are often smaller than mature, nonentrepreneurial firms. Several studies have found that many SMEs struggle heavily

\footnotetext{
${ }^{42}$ See, e.g., OECD (2007) and EU (2008) for a further discussion.

${ }^{43}$ Ho and Wong (2007). In a highly influential paper, Djankov et al. (2002) discuss and analyze entry costs across 85 countries.

${ }^{44}$ See, e.g., World Bank (2005a, 2005b). The methodology is based on Djankov et al. (2002), which is greatly inspired by de Soto (1989).

${ }^{45}$ See, e.g., Desai et al. (2003), and Klapper et al. (2004).

${ }^{46}$ Ho and Wong (2007).

${ }^{47}$ Dean and Meyer (1996).

${ }^{48}$ OECD (1998).

${ }^{49}$ Nijsen (2000).
} 
with administrative regulations SMEs ${ }^{50}$ Hence, a high regulatory burden penalizes entrepreneurial expansion.

More than just the level of the administrative burden matters, however; ambiguous and opaque legislation —including vaguely formulated rules, frequent changes, and exemption clauses - also hampers entrepreneurial initiatives. ${ }^{51}$ Many entrepreneurs lack the resources to devote their own time or pay an employee to cope with bureaucratic red tape and unpredictable changes and delays in relevant legislation. $^{52}$

A high regulatory burden influences necessity entrepreneurship and opportunity entrepreneurship differently. Potential necessity entrepreneurs usually possess less wealth; regulatory costs can upset their financial status and deter them from entrepreneurship. ${ }^{53}$ On the other hand, potential opportunity entrepreneurs normally possess more wealth, but they have more options (notably, to continue being a wage earner), which in turn makes them sensitive to start-up costs. ${ }^{54}$ In contrast, potential high-impact entrepreneurs who expect large gains are less likely to be deterred by a regulatory burden, granted that the expected gain is high enough. ${ }^{55}$

However, costly regulation not only affects the level (and form) of entrepreneurship, but also its distribution between the formal and informal sector. Excessive regulation tends to push entrepreneurial activity into the informal sector, breeding corruption and stimulating unproductive entrepreneurship. ${ }^{56}$ Lowering administration costs thus shifts business activities from the informal to the formal sector. ${ }^{57}$ Given that entrepreneurship in the formal sector is preferred and more productive, lowering entry barriers and administrative costs stimulates productive entrepreneurship.

\footnotetext{
${ }^{50} \mathrm{EU}$ (2008). Crain and Hopkins (2001) found that the total cost of federal regulation in the US is about 45 per cent greater per employee in small firms $(<20)$ relative to large firms $(>500)$.

${ }^{51}$ Audretsch et al. (2002).

${ }^{52}$ Kauffman Foundation (2008).

${ }^{53}$ van Stel et al. (2007, p. 173). Ho and Wong (2007) claim, however, that necessity entrepreneurship should not be hampered by regulatory costs, as they are driven by lack of alternative employment and not by exploiting new profitable opportunities.

${ }^{54}$ Ho and Wong (2007).

${ }^{55}$ Ho and Wong (2007).

${ }^{56}$ de Soto (1989), and Henrekson and Sanandaji (2010).

${ }^{57}$ Cf. Baumol (1990). Capelleras et al. (2008) find support for this idea. They show that there is lower business activity in Spain's highly regulated formal sector than in the less regulated UK. This difference disappears, however, if the informal sector is included in the analysis.
} 
In response, many countries have attempted to ease the regulatory environment to stimulate entrepreneurship by reducing the number of permits required to start a business, for example, or cutting the minimum time needed to obtain such permits. This has stimulated business creation in many countries. ${ }^{58}$

However, lower levels of regulatory barriers may also have counterintuitive effects. Rodrik (2007) has pointed out that the easier it is to start a new business, the easier it is to imitate the initial innovator and capture a share of his profits. If entry barriers are too low, the incentive to introduce innovations is too low as well. Research has shown that the number of new products being exported is positively related to the height of entry barriers. ${ }^{59}$

Entry barriers can also influence the quality of entrepreneurs and their ventures. More stringent entry requirements may increase the average quality of new ventures and their survival rate. ${ }^{60}$ The more difficult it is to enter the market, the higher the chance of surviving and succeeding once a firm has entered. When entry is easy ventures with a lower likelihood of success are worth attempting. Hence, lowering entry barriers may increase the quantity of entrepreneurs but decrease their quality. In theory low entry barriers could therefore have a detrimental effect on the aggregate economy. However, we deem that this is unlikely to be the case in practice. It is also easy to find research which shows that the quality does not deteriorate when entry requirements are relaxed. ${ }^{61}$

\subsubsection{Liquidity and capital constraints}

Entrepreneurial activity hinges on accessing and raising capital of the right kind. Numerous studies show that access to capital is the most significant obstacle for many business launches. ${ }^{62}$ Yet many start-ups do not require much capital; financial constraints do not pose a problem for many new businesses. ${ }^{63}$ Advances in ICT have also reduced minimum capital requirements in many markets. ${ }^{64}$ As it stands, capital

\footnotetext{
${ }^{58}$ OECD (2005), and Haggarty et al. (2006).

${ }^{59}$ Klinger and Lederman (2006).

${ }^{60}$ Audretsch et al. (2002).

${ }^{61}$ See, e.g., Audretsch et al. (2002).

${ }^{62}$ See, e.g., Parker (2004, section II), and van Auken (1999).

${ }^{63}$ Hurst and Lusardi (2004), and Shane (2008, p. 79).

${ }^{64}$ Baumol et al. (2007, p. 236).
} 
tends to constrain high-growth firms more ${ }^{65}$ because they often require sizable infusions of funds to sustain growth. Liquidity constraints also become more binding as companies get smaller. ${ }^{66}$

In the EU, entrepreneurs and SMEs rank financing as their second most important concern after administrative burden. ${ }^{67}$ The United States' highly developed financial system has indeed been cited as responsible for the emergence of its successful entrepreneurial economy. ${ }^{68}$

\section{The general problem}

Banks normally demand collateral-based lending. This requires that the potential entrepreneur has enough resources of his own to invest in the project or to use as collateral. A mixture of information asymmetries and the inherent risk of entrepreneurial projects lies at the heart of the problem. A potential entrepreneur understands more about his own ability and his entrepreneurial investment project than his prospective lender. Reducing the obstacle of asymmetric information by screening (by the potential lender) and signaling (by the potential entrepreneur) can be problematic because of the entrepreneur's lack of a track record or the difficulty of evaluating his project.

Entrepreneurs can circumvent the asymmetric information problem by investing personal resources in the project, as this signals that the entrepreneur believes that the project has a high likelihood of success. Banks do normally also demand collateral-based lending. This obviously requires that the potential entrepreneur has enough resources of his own to invest in the project or to use as collateral. Hence, own financing or collateral lending may signal both high confidence in the project and access to wealth. However, potential entrepreneurs without enough wealth cannot signal confidence in this way (even if they have high faith in their project).

From a first-best perspective, the desirable outcome is obvious: good projects should be funded, bad ones should not. Good projects should be pursued even if the

\footnotetext{
${ }^{65}$ Baumol et al. (2007, p. 205).

${ }^{66}$ Fazzari et al. (1988).

${ }^{67}$ EU (2008).

${ }^{68}$ Kauffman Foundation (2007, p. 34).
} 
entrepreneur lacks requisite funds. (And bad projects should not be pursued even if the entrepreneur has the necessary resources.) Not all projects should be financed. A failure to raise funds is by no means an example of market failure or capital market malfunction. The credit market functions as an initial filter, screening out the most unrealistic and overly optimistic projects. A bank or a venture capitalist, with many years of experience financing entrepreneurial ventures, may make better judgments than a first-time entrepreneur. ${ }^{69}$ Moreover, many entrepreneurs are grossly overoptimistic about the future success of their projects. ${ }^{70}$

Research has found that the probability of becoming an entrepreneur increases with wealth - financial constraints curtail entrepreneurial activity. However, causality may run in the other direction; wealthier persons may be more likely to be better entrepreneurs on average. ${ }^{71}$ Other studies have also shown that receiving an inheritance does not increase one's likelihood of starting a business, which casts doubt on the importance of financial constraints. ${ }^{72}$

Although these objections must be considered, it would be too harsh to conclude that financial constraints never pose a problem. Even if an appropriate amount of projects are funded, their quality could still leave much to be desired. After all, the problem could be qualitative rather than quantitative. Plenty of other research indicates that capital resources increase the ability to survive and expand. ${ }^{73}$

This first-best perfect information approach, which underlies some of the arguments above, may also be misleading. It is impossible to know ex ante whether a project will be successful. Testing new ideas in the marketplace is the entrepreneur's fundamental task - in practice, all failed projects do not represent a waste of resources or a market failure. However, every opportunity to use scarce resources more efficiently thwarted by financial constraints gives rise to a welfare loss. Being an

\footnotetext{
${ }^{69}$ See de Meza (2002) and de Meza and Southey (1996) for an in-depth discussion. de Meza actually claims that too many low-quality projects are being funded due to asymmetric information. The problem is then that too many projects are financed. In accordance, he argues that public policy should be used to reduce lending to entrepreneurs.

${ }^{70}$ See, e.g., Hayward et al. (2006) who discuss the Hubris theory of entrepreneurship; many potential entrepreneurs have overconfidence in their knowledge, predictions, and personal ability.

${ }^{71}$ See Shane (2008, chapter 5) for an interesting discussion.

${ }^{72}$ Hurst and Lusardi (2004). Nykvist (2008) examines this relationship using similar methods with Swedish data, but the result that wealth is not important for new entrepreneurs could not be replicated.

${ }^{73}$ Kauernman et al. (2005), and Bamford et al. (2004).
} 
agent of change who combines production factors in novel ways, the entrepreneur holds center stage in the market's selection process.

\section{Financing entrepreneurship in practice}

A start-up's success relies on the availability of equity financing. In general, reliance on equity rather than debt financing increases with risk. The smaller and newer the firm is, the more difficult it is for outside financiers to assess the viability and profitability of the venture. Thus, ceteris paribus, small and newly established firms are more dependent on equity financing than large, well-established firms.

Entrepreneurial start-ups struggle to raise funds from large financial institutions and thus often rely on insider and internal funding in the enterprise's nascency. Internal financing can be increased in this phase by pursuing economic policies that promote private wealth accumulation in forms that do not preclude the assets from being used as equity in entrepreneurial ventures. ${ }^{74}$

Research strongly suggests that incentives for individual wealth accumulation would likely increase entrepreneurial activity. ${ }^{75}$ Low private savings exacerbate the inherent problem caused by asymmetric information, as discussed above. Wealthconstrained would-be entrepreneurs are unable to forcibly signal their project's worth to outside investors by means of making sizeable equity infusions of their own or, if needed, to fully finance the firm until organic growth based on retained earnings is possible.

Informal investors, mainly so-called business angels, fill this gap between internal funding and formal venture capital financing. New research has shown that the availability of these informal investors is crucial in overcoming liquidity constraints. ${ }^{76}$ The United Kingdom has in particular used tax reliefs and generous deductions to encourage business angel investments. ${ }^{77}$

\footnotetext{
${ }^{74}$ Pelikan (1988) provides forceful arguments supporting this view. Data from the US show that businesses below two years of age are equity financed to 48 percent, in which the bulk comes from internal sources. Consequently, debt financing constituted 52 percent, but only 28 percent of the debt consisted of funding from financial institutions (Berger and Udell 1988).

${ }^{75}$ See Parker (2004), and Nykvist (2008).

${ }^{76}$ Ho and Wong (2007).

${ }^{77}$ An example is the Enterprise Initiative Scheme, introduced in 1994, which under certain conditions give business angel investors tax relief from capital gains and the possibility to write off the amount invested (up to a cap) against income tax. See, e.g., Boyns et al. (2003) and Mason (2006).
} 
Venture capital firms play a pivotal role in the development of small entrepreneurial ventures by converting high-risk opportunities to a more acceptable risk level through portfolio diversification and adding key competencies that the firm may be lacking. Although the importance of the formal venture capital industry has increased over time, its extent is still rather modest. ${ }^{78}$ As already noted, many entrepreneurial firms are too small for venture capital funding. Yet venture capital retains importance for high-performing and high-growth entrepreneurial firms. ${ }^{79}$ Venture capital is often superior to bank finance since it also provides key expertise and access to networks important for entrepreneurial high-risk firms. ${ }^{80}$

The venture capital industry is less developed in Europe than in the US. ${ }^{81}$ This may occur because European business owners are less prone to accept loss of control, a normal implication of venture capital support. ${ }^{82}$ US firms also grow faster than their European counterparts, which tend to remain small. ${ }^{83}$

The government can support the venture capital industry both directly and indirectly. ${ }^{84}$ The government can use tax revenues to directly provide venture capital to the market, either through state controlled organizations or together with private actors. The government could in particular support the supply of early stage (seed) capital — which the formal venture capital industry typically does not providethrough public interventions.

However, there is reason to be skeptical of this kind of direct support. Any support system must contain elements of rationing and selection in order to avoid moral hazard problems of unmanageable proportions. No recipe dictates how to "pick the winners" and support the right investments. On the contrary, the process of evaluation in the private venture capital industry is both highly complex and sophisticated, and often includes tacit judgments. The industry is at best moderately

\footnotetext{
${ }^{78}$ See, e.g., Reynolds et al. (2002), and Bygrave and Hunt (2004).

79 OECD (1998).

${ }^{80}$ Ho and Wong (2007), and Keuschnigg and Nielsen (2004a).

${ }^{81}$ See, e.g., Bottazzi and Da Rin (2002) and Da Rin et al. (2006),

${ }^{82}$ OECD (1998).

${ }^{83}$ Scarpetta et al. (2002).

${ }^{84}$ Borger et al. (2000).
} 
successful in picking the winners among high-risk projects, despite their specialization in this area. ${ }^{85}$

Neither theory nor practice indicate that politically controlled organizations are better able than the private venture capital industry (or business angels) to assess the likelihood of business success. On the contrary, politically controlled organizations might — directly or indirectly, openly or furtively, partly or completely - base their decisions on political rather than commercial criteria and therefore underperform. ${ }^{86}$ Examples of politically controlled organizations that have outperformed private organizations in this area are hard to find. ${ }^{87}$ To counter this objection, state-governed venture capital could be compelled to only fund firms that also receive private funding in order to copy and reinforce the emerging funding structure on the market. ${ }^{88}$

The government can also support the venture capital industry indirectly. It could, for example, stimulate the private venture capital industry through tax policy. The 1980s witnessed the rapid growth of the US venture capital industry in just this fashion, spurred by large cuts in capital gains taxes. ${ }^{89}$ Around 1980, the US legal framework began encouraging the development of a sophisticated venture capital industry. The industry itself then designed a number of efficient incentive schemes to

\footnotetext{
${ }^{85}$ See, e.g., Gompers and Lerner (2004) or Gompers et al. (2009). Cf. Birch (2006), who claims that it is impossible to "pick winners". Svensson (2008) has also shown that soft public financing in the early stage (seed) phase often leads to inferior firm performance and that public loans always should be granted on commercial terms. See also Bergström (2000).

${ }^{86}$ However, openly and politically influenced decisions are at times deliberate support of, e.g., impoverished regions. Supporting specific minority groups, like immigrants or women, may also be a way to compensate for possible (credit market) discrimination in the economy.

${ }^{87}$ Baumol et al. (2007, p. 220).

${ }^{88} \mathrm{Cf}$. Shane (2008) who claims that politicians should think like venture capitalists and copy their strategies instead of supporting the "typical" venture with a supposedly low impact on the economy. Politicians cannot "pick winners" but they can try to avoid "picking losers". Baumol et al. (2007) asserts that the Advanced Technology Program (ATP), administered by the Commerce Department in the US, only supported ventures which also attracted private money and there is some support that this has been successful. The largest program in US is the Small Business Innovation Research (SBIR) program. Program evaluation can be very complex, but Siegel et al. (2003) concludes that both ATP and SBIR have been successful.

${ }^{89}$ Gompers and Lerner (1999) find that a crucial factor behind the growth of the US venture capital industry was that the decrease of capital gains tax rates boosted demand for venture capital as more workers got an incentive to become entrepreneurs. Keuschnigg and Nielsen (2004b) have shown theoretically that inefficiently low entrepreneurial effort and venture capital support may arise in the economy and that capital gains taxation may be particularly harmful. See also Keuschnigg and Nielsen (2004a) for an additional discussion.
} 
overcome inherent conflicts of interest between innovators, entrepreneurs, fund managers, and investors. ${ }^{90}$

New research based on European data cast doubt on the idea that channeling more funds into venture capital markets automatically stimulates a successful venture capital industry. A successful VC industry is more likely to be stimulated if the expected return of innovative projects were higher due to, e.g., decreased corporate or capital gains taxation. The existence of exit opportunities also spurs the venture capital industry. ${ }^{91}$ Although the problem of information asymmetries cannot be solved by means of tax policy, an appropriate tax policy can trigger informal and formal venture capital to alleviate these problems.

Focus should not, however, remain fixed on the venture capital industry. A well-developed financial sector offers a spectrum of other financial sources, ranging from readily available, highly liquid savings to long-term institutionalized pension saving schemes that severely restrict the owner's control of the assets. In many countries, long-term pension savings constitute the bulk of personal savings. In addition, pension savings are often tax favored. Peter Drucker warned against these tendencies more than thirty years ago, claiming that the sharp increase of corporate pension plans posed a dire threat to the entrepreneurial society-it concentrated too much power in too few hands. ${ }^{92}$

Hence, the composition of savings — not just the volume-sways potential entrepreneurship activity in the economy. For this reason, any arrangement that channels savings and asset control to large institutional investors will likely limit the supply of financial capital to potential entrepreneurs. In 1978, the US began allowing pension funds to invest a portion of their assets in high-risk projects. This contributed to a significant expansion of the VC industry that, in the end, boosted entrepreneurial activity. ${ }^{93}$

\footnotetext{
${ }^{90}$ Henrekson and Rosenberg (2001).

${ }^{91}$ Da Rin et al. (2006). They conclude: "[T] $]$ he European experience suggests that the creation of active venture capital markets might depend on providing investors and entrepreneurs with the possibility to reap the benefits of their efforts rather than providing them with more funds."

${ }^{92}$ Drucker (1976).

${ }^{93}$ Hart (2003, p. 10).
} 


\subsubsection{The labor market}

Labor market and wage-setting regulation can influence incentives for entrepreneurship since it restricts the freedom of contracting and therefore curtails possible combinations of factors of production. Labor security regulations fall more heavily on younger, smaller, and less capital-intensive employers. As entrepreneurial firms are overrepresented in these categories, labor security regulation disproportionally burdens entrepreneurial firms.

As a highly regulated economy is too rigid to adapt well to changes, employment flexibility may be important for entrepreneurial activities. Strong regulation of the employment and dismissal of employees keeps entrepreneurs from adjusting their workforce in correspondence with market fluctuations, thereby increasing the risk of their projects even further. ${ }^{94}$ As an employer determines a worker's abilities over time, and as those abilities evolve with the accumulation of experience, his optimal work assignment will also likely change. In a flexible labor market, this often entails worker mobility between firms; such mobility is more likely to occur when the initial employment relationship was forged in a small, often young, business.

Labor market regulation can directly influence entrepreneurial activity through two channels. First, a low level of labor market regulations increases the flexibility of high-risk entrepreneurial companies, making it more attractive to be an entrepreneur. Second, the relative advantage of being an employee decreases with weak employment protection laws, making it more favorable to undertake entrepreneurial projects as self-employed. ${ }^{95}$ Generous, far-reaching labor protection laws increases an employee's opportunity cost of changing employers or leaving a secure salaried job to become self-employed.

The extent of labor market regulations differs greatly across countries. OECD has compared the extent of government regulations on labor standards by measuring five different aspects. ${ }^{96}$ Of the 18 countries included in the survey, Greece and Sweden exhibited the highest index value ( 8 and 7 points). The average for all European countries was 4.9. The US scored a zero and Canada $2 .{ }^{97} \mathrm{New}$ research has

\footnotetext{
${ }_{94}^{94}$ Audretsch et al. (2002, p. 47).

${ }^{95}$ van Stel et al. (2007).

${ }^{96}$ OECD (1994).

${ }^{97}$ OECD provided an update of the 1994 study in 2009. See Skedinger (2010) for details.
} 
found that the differences in labor market regulations shape the level of nascent entrepreneurship more than entry regulations. Entrepreneurship tends to be higher in countries where it is relatively easy to hire and dismiss employees. ${ }^{98}$

Labor market deregulation can and has stimulated entrepreneurial activities in many OECD countries. ${ }^{99}$ Small firms in the Netherlands, for example, hire fewer employees than needed due to the perceived cost of formal rules and regulation. ${ }^{100}$ New firms in the US on the other hand, expand their employee base more rapidly than firms in Europe. ${ }^{101}$ Europe's stricter employment protection laws probably induce the relative lack of new, rapidly growing firms in Europe. ${ }^{102}$

Labor market regulations thus deter and impede business activities. If regular employment is highly regulated, however, a strong incentive to circumvent these regulations may develop. Potential entrepreneurs can do so by pursuing entrepreneurial projects as self-employed, using only self-employed labor instead of hiring employees if labor is needed. Compensation and working hours are totally unregulated and no labor security is mandated for the self-employed. This may boost the level of self-employment, but it should not be interpreted as a sign of exuberant entrepreneurial activity. Instead, it is a costly, albeit necessary, measure to evade the effects of stringent labor market regulation. Part of the increase in self-employment in recent years in many highly regulated economies is likely driven by such considerations.

Given the large intra-firm differences in productivity and productivity growth, wages set in negotiations away from the workplace that do not take idiosyncratic factors into account will impair entrepreneurial activities. Intra-firm differences are especially large in young and rapidly expanding industries and firms. ${ }^{103}$ In developed countries, employees' general income level is also relatively high, which in turn

\footnotetext{
${ }^{98}$ van Stel et al. (2007).

${ }^{99}$ OECD (1998, 2000).

${ }^{100}$ Niehof (1999).

${ }^{101}$ OECD (2003).

${ }^{102}$ Baumol et al. (2007, pp. 210, 222).

${ }^{103}$ See Caballero (2007).
} 
makes the opportunity cost of leaving salaried employment to start or work in a new venture high as well. ${ }^{104}$

Very small firms can avoid unionization and collective agreements, and therefore benefit from greater freedom of contract. This room for maneuvering would likely disappear once the firm size exceeds a certain threshold, thus increasing the cost of expansion. This is yet another factor likely to hamper the entrepreneurial spirit and willingness to grow among new and small enterprises. As a result, a tightly regulated labor market may create a system in which a large share of economic activity occurs in small firms lacking the ability or the ambition to grow. Onerous regulation makes it difficult and risky to build large companies. Italy is a good case in point, where firms tend to remain small and resort to cooperating with other small firms in clusters. ${ }^{105}$ By contrast, new firms in the US tend to expand their businesses more rapidly than the European counterparts.

\subsubsection{The social security system}

The social security system is closely linked to the labor market regulation discussed above. The establishment of public income insurance systems in combination with stringent labor security legislation tends to penalize individuals who assume entrepreneurial risk. ${ }^{106}$

That social security schemes in modern welfare states tend to deter entrepreneurial activity stems from the relative advantage of being an employee. Many social security benefits, such as disability, sickness, and unemployment benefits, are explicitly linked to formal employment. The opportunity cost of leaving a tenured position as an employee is high, strengthening preferences for regular employment and reducing the incentives for entrepreneurship. ${ }^{107}$ Generous pension benefits paid by employers have a similar effect.

However, even if it were possible to generalize the social security system, the self-employed and owners/managers of small entrepreneurial firms would not be able

\footnotetext{
${ }^{104}$ Ho and Wong (2007).

${ }^{105}$ Lazerson and Lorenzoni (1999), and Pyke et al. (1990).

${ }^{106}$ See, e.g., Ilmakunnas and Kanniainen (2001) for an econometric analysis of the effects of risk insurance in the welfare state.

${ }^{107}$ See, e.g., Audretsch et al. (2002).
} 
to use sick or parental leave benefits, for example, in practice. Their increased exposure to risk and lower social security protection is a natural part of being an entrepreneur. Many are therefore unwilling to forgo a large part of their social security protection in exchange for uncertain entrepreneurial incomes. Making part of social insurance benefits "portable" between jobs and between regular employment and self-employment would reduce this effect.

Beside the differences in social security protection between employees and many entrepreneurs, the level of benefits may matter as well. Generous unemployment benefits discourage the unemployed from becoming self-employed (as a form of necessity entrepreneurship) and reduce the number of individuals willing to enter into entrepreneurial ventures as employees. In countries where the unemployed receive a high proportion of their former wage, the rate of new firm formation is lower. ${ }^{108}$ In a study of people among Swedish business start-ups with at least three years of university education in science, technology or medicine, employees and students often preferred unemployment and further education to starting a business of their own when faced with unemployment. ${ }^{109}$

The health care insurance system poses additional problems. In many countries, notably the US, health insurance is tied to employment. Many workers and potential entrepreneurs get "trapped" in large companies that provide generous health insurance for the employee and his/her family. Decoupling health insurance from employment would increase labor flexibility and reduce fears of loosing adequate health insurance.

\subsubsection{R\&D, commercialization and knowledge spillover}

The successful exploitation of research and inventions combined with the transfer and spillover of this knowledge stimulates growth and prosperity in a modern economy. ${ }^{110}$ The entrepreneur plays an important role in this respect. Entrepreneurs — in both new and established ventures - are responsible for recognizing unexploited opportunities in the market and spreading innovations by imitation and incremental improvements

\footnotetext{
${ }^{108}$ Nickell (1997), and Koellinger and Minniti (2009).

${ }^{109}$ Delmar et al. (2005).

${ }^{110}$ See, e.g., Acs et al. (2009).
} 
of existing technologies. ${ }^{111}$ An important objective of entrepreneurship policy is to promote this process of production and commercialization of knowledge.

Entrepreneurship policy is often justified by noting the key importance of knowledge spillovers. $^{112}$

At present, politicians of all persuasions stress "the knowledge economy" and virtually all of them seem to have a similar policy prescription to promote this kind of economy: more R\&D spending. ${ }^{113}$ This idea is, however, based on an overly mechanical view of the economic system. Higher spending on R\&D does not automatically produce more innovations or more entrepreneurs who start new or expand existing ventures. Without a well functioning entrepreneurial economy, the full potential from increased R\&D cannot be reaped. New ideas and inventions are only the first step in an innovation and commercialization process. For increased R\&D to translate into economic growth, entrepreneurs must exploit the inventions by introducing new products on the market or introducing new methods of production. ${ }^{114}$

In the worst case, quantitative goals can be a waste of money as focus and resources are directed towards factors which may not be exploited at all or be exploited elsewhere. ${ }^{115} \mathrm{R} \& \mathrm{D}$ spending is a factor input, not an output, and should not be subject to quantitative political goals. It has no such intrinsic value from an economic point of view. Although high R\&D spending can be a necessary part of a successful economy of today, it is far from sufficient. ${ }^{116}$

\footnotetext{
${ }^{111}$ Baumol (2002).

112 See, e.g., Acs (2008).

113 See, e.g., EU (2002).

${ }^{114}$ Bhidé (2008).

${ }^{115}$ The amount of R\&D may not only be large but also exploited inefficiently. Da Rin et al. (2006) examined 14 European countries in a panel between 1988 and 2001 and did not find any positive relationship between public R\&D spending and the rate of innovation, defined as the share of high-tech and early stage venture capital investments.

${ }^{116}$ To make the point crystal clear: it was neither Bill Gates nor Henry Ford who invented the technologies they used in their ventures. They were entrepreneurs who successfully exploited new or existing technologies. These entrepreneurs were needed to successfully exploit the inventions. Only focusing on inventions and R\&D misses at least half of the story. Increased R\&D will not automatically bring forth entrepreneurs undertaking entrepreneurial activity based on new R\&D. Perhaps it is even the other way around, i.e., in an economic system encouraging productive entrepreneurship a great deal of $\mathrm{R} \& \mathrm{D}$ is undertaken because the results from $\mathrm{R} \& \mathrm{D}$ are demanded (Holcombe 2007).
} 
The so-called knowledge spill-over theory of entrepreneurship offers an alternative perspective. ${ }^{117}$ This theory relaxes two implicit or explicit assumptions of earlier theories. First, it distinguishes between knowledge and "economic knowledge", namely knowledge that is economically exploitable - more knowledge does not automatically translate into more economic knowledge. Second, it rejects the assumption that (economic) knowledge automatically spills over and induces growth. The entrepreneur enlivens these roles instead. They are the actors who commercialize inventions and thereby transform knowledge into economic knowledge, and they are the origin of knowledge spillover throughout the economy.

Knowledge is often tacit, sticky, and uncertain, making it both costly and difficult to transmit and evaluate. As it is uncertain, the expected value and variance of an innovation will differ between individuals. This lays bare high profit opportunities for new entrepreneurial firms which incumbent firms either do not recognize or do not realize. Spinoffs also become possible. If incumbents fail to see high enough profit opportunities in ideas launched by their employees, the employees can instead exit the companies and start new entrepreneurial firms.

Geographic proximity also facilitates knowledge spillover and knowledge transfer. If public policy promotes networks through which knowledge can easily be transferred between businesses and organizations, entrepreneurship is facilitated as a result. ${ }^{118}$ Clusters and science parks supported by public policies make sense from this perspective. A Swedish study comparing new technology-based firms found a slight overperformance for firms situated in science parks. ${ }^{119}$ Today's most dynamic clusters, however, cannot be traced to a certain policy measure; cluster formation is a longterm process which cannot be accelerated by means of a quick policy fix.

An element of serendipity characterizes all cluster formations. Consequently, public policy plays a greater role in the later phases of cluster formation. Successful clusters normally emerge in response to opportunities - a successful cluster cannot be created by public policy. At the end of the day, the competence of creative, persistent entrepreneurs seems to outweigh geography in the formation of successful clusters. ${ }^{120}$

\footnotetext{
${ }^{117}$ See, e.g., Acs (2008) and Acs et al. (2009) for a further discussion.

${ }_{118}$ Audretsch et al. (2002).

${ }^{119}$ Lindelöf and Löfsten (2003).

${ }^{120}$ Carlsson (2009).
} 
However, this form of support should not be directed to specific firms. Firms must be self-selected and not "picked" (see section 4.1.6 for further discussion).

Public policy can instead sustain business infrastructure with different facilities. Google and Netscape provide two interesting examples of innovations originating from university campuses. Stimulating academic entrepreneurship and accelerating the commercialization of university-developed innovations can be one way to foster innovation in the economy. ${ }^{121}$ For this to be successful, university faculty must encourage and stimulate entrepreneurial initiatives at the same time as incentives for university spinoffs remain strong. Some universities have a Technology Transfer Office, or TTO, an in-house organization specializing in assisting academic entrepreneurs in commercializing their inventions. But a TTO could also hinder the commercialization of useful technologies by making the process too bureaucratic and seeing to its own narrowly-defined proprietary interests. ${ }^{122}$

\subsubsection{Targeted support}

The policies discussed so far have all been general in nature. However, more specific public policies can target firms (SMEs), occupations (self-employed), regions (underdeveloped, rural), sectors (ICT, biotech), or individual groups (women, blacks, immigrants, and unemployed). These groups could be perceived to be more important for entrepreneurship (e.g., SMEs or the ICT-sector), or found to be lacking in entrepreneurial activity (e.g., young people, women).

As discussed in the opening sections, entrepreneurship policy takes a more general stance and tries to stimulate productive entrepreneurial initiatives independent of firm and individual characteristics. One should be wary of using targeted policies because of their negative side-effects. For instance, subsidizing small firms increases small firms' cost of growth (beyond a certain threshold). If policy aims to encourage a

\footnotetext{
${ }^{121}$ Kauffman Foundation (2007).

${ }^{122}$ Kauffman Foundation (2008), and Baumol et al. (2007). See also Henrekson and Rosenberg (2001). There are innumerable examples of programs supporting science parks, clusters, and spin-offs, especially within the academic sector. Even if many studies find a positive effect from these programs, fair evaluations are difficult due to endogeneity problems and a lack of a counterfactual benchmark (how institutional arrangements would have spontaneously evolved had there been no public support). There are, however, also examples of failed policy programs such as the UK support program for young people (Meager et al. 2003). See OECD (2007) for a further discussion of evaluations of entrepreneurship policies and programs.
} 
robust and dynamic business sector, such a program is largely misdirected. ${ }^{123}$ Supporting the unemployed also tends to have undesirable side-effects. The unemployed are more likely to start new ventures than their employed counterpartseven without government support — and their ventures are more likely to fail. Pushing more unemployed into self-employment is unlikely to increase the success rate in this category and should be treated with skepticism. ${ }^{124}$

\subsection{Rewards for productive entrepreneurship}

Entrepreneurs generally strive for a combination of wealth, power, and prestige. ${ }^{125}$ Low costs to start and expand a business alone will not entice an entrepreneur to exploit an opportunity; the expected reward must be large enough to compensate for the opportunity costs and uncertainty incurred. ${ }^{126}$ This section discusses how public policy can stimulate entrepreneurship by rewarding productive entrepreneurship. Tax policy plays a major role in this respect, and its effects constitute a substantial part of this section as a result.

\subsubsection{Property rights}

Private property rights - the existence of legal titles to hold property and the protection thereof - is arguably our most fundamental economic institution. ${ }^{127}$ The establishment of secure and stable property rights steered the long-term development of Western countries. ${ }^{128}$ Secure property rights ensure that physical objects can be turned into capital, a transformation that requires judgment, imagination, and innovation. ${ }^{129}$ Without control over assets and their returns, a potential entrepreneur will lack the incentive to innovate. ${ }^{130}$ In countries with weak property rights,

\footnotetext{
${ }^{123}$ Holtz-Eakin (2000, p. 288).

${ }^{124}$ Audretsch et al. (2002, p. 55). Research based on UK data also shows that targeted regional start-up subsidies to underperforming regions tends to encourage individuals with limited human capital to start firms. This group seldom develops high-impact firms and often leaves the market after some time. See van Stel and Storey (2004).

${ }^{125}$ Baumol et al. (2007, p. 234).

${ }^{126} \mathrm{Cf}$. Ho and Wong (2007).

${ }^{127}$ See, e.g., Libecap (1993), Baumol (2002), Rodrik et al. (2004), and Acemoglu and Johnson (2005).

${ }^{128}$ Rodrik (2007), and North and Weingast (1989).

${ }^{129}$ de Soto (2000).

${ }^{130}$ Rodrik (2007, p. 156). Rodrik stresses the importance of control. Formal property rights which in practice do not render control rights are useless. In the same way, even if formal property rights are
} 
entrepreneurs are discouraged from reinvesting retained earnings in their ventures. ${ }^{131}$ The division and specialization of labor are also hampered, which narrows the range of potential entrepreneurial discoveries.

Moreover, weak property rights (and the protection thereof) stimulate unproductive and destructive entrepreneurship. If the protection of property rights is sufficiently weak, destructive entrepreneurship, such as extortion and corruption, will be promoted. Hence, in light of insufficient and inadequate laws to protect and ascertain private property rights, unproductive and destructive entrepreneurship is strengthened relative to productive entrepreneurship. Organized crime syndicates and the mafia, for example, are often innovative in their response to shortcomings in the legal enforcement framework, and pursue entrepreneurship as a substitute for absent or maladaptive public institutions. The Sicilian mafia and criminal organizations in Japan illustrate that these activities are not necessarily negative for the economy, given the context within which they are carried out. ${ }^{132}$

Intellectual property rights and patent legislation are important questions in this area. We will discuss this issue in section 4.4.1.

\subsubsection{Taxation}

The tax system represents a key public policy tool in setting the level of rewards of entrepreneurship. The extent and design of the tax system affects the net return to entrepreneurship both directly and indirectly. It determines a potential entrepreneur's risk-reward profile and consequently his incentives for undertaking entrepreneurial activities as well. Even if non-pecuniary rewards unaffected by taxes (such as autonomy and individual flexibility) also matter, the financial effects from taxation cannot be neglected. Extensive research has analyzed theoretical and empirical effects of the tax system; its effects are, however, often complex and sometimes counterintuitive.

absent, sufficiently strong control rights may be enough to provide sufficient incentives for potential entrepreneurs.

${ }^{131}$ See Johnson et al. (2002) who investigates new firms in the post-communist countries.

${ }^{132}$ Bandiera (2003), and Milhaupt and West (2000). See Douhan and Henrekson (2010) for a further discussion. 
From a theoretical point of view, the tax system affects entrepreneurial activity through a variety of mechanisms. The theoretical literature identifies four main channels: (1) an absolute effect affecting the supply and effort of potential entrepreneurs in the economy; (2) a relative effect affecting an individual's choice of occupation and organisational form; (3) an evasion effect affecting the willingness to become an entrepreneur to take advantage of opportunities to decrease the tax burden; and (4) an insurance effect affecting the amount of risk people are willing to assume and hence the likelihood of undertaking entrepreneurial activities. ${ }^{133}$ We will discuss each of these effects below.

The absolute effect of a tax makes it more expensive to start or expand a business; an absolute increase of taxation of entrepreneurs lowers the (expected) after tax reward. It also makes expansion financed by retained earnings more difficult and negatively affects the liquidity position of an entrepreneur. A lower after tax return or higher expansion costs discourages entrepreneurial activities and impedes new startups and the expansion of firms. ${ }^{134}$

Taxation may also alter the relative return of different activities if it favors one form of employment over another. As a result, a higher tax rate may encourage income shifting and thus positively influence (some form of) entrepreneurship in the economy.

The evasion effect arises if evading taxes on entrepreneurial income either illegally or legally is simpler than paying them. This often proves true for entrepreneurs working as self-employed. ${ }^{135}$ It may be easier for self-employed to underreport income by avoiding registration of cash sales or to overstate costs by recording private expenses as business costs, or to frequently use more informal agreements that are hard for the tax authority to verify or disclose. A Swedish study estimates that the self-employed underreport their income by 30 per cent. ${ }^{136}$ Higher taxes may, as a result, encourage entrepreneurship (i.e., self-employment). When a

\footnotetext{
${ }^{133}$ These effects can, e.g., be compared to Slemrod (1986) who only distinguishes between two effects to tax changes: real responses and avoidance responses.

${ }^{134}$ See, e.g., the discussion in OECD (1998).

${ }^{135}$ See, e.g., Long (1982), Watson (1985), Kesselman (1989), Pestieau and Possen (1991) for a discussion of tax evasion and choice of occupation. Robson and Wren (1999) conclude that it is mainly the average tax rate that affects evasion behavior.

${ }^{136}$ Engström and Holmlund (2009).
} 
business expands above a certain level, it becomes more difficult to exploit such tax avoidance opportunities. $^{137}$

Lastly, the insurance effect claims that taxation (with full loss offset) functions as insurance that stimulates risk-taking. ${ }^{138}$ When applied to entrepreneurship, an increased tax on the net return together with full loss offset will reduce the after tax variance of profits and hence the risk associated with the business. If potential entrepreneurs are risk averse, this risk reduction may stimulate entrepreneurship. ${ }^{139}$

However, the rate of tax progression may also matter. The insurance effect assumes a proportional tax rate with full loss offset. Given that entrepreneurial incomes are more variable than salaried income, the average tax will be higher for entrepreneurs in a progressive tax system. A highly progressive tax system with imperfect loss offset therefore deters entrepreneurial business entry. ${ }^{140}$ High marginal tax on entrepreneurial income (for high incomes) penalizes gazelles, or high-growth entrepreneurial ventures. ${ }^{141}$

In sum, theory argues for both a positive and a negative relationship between taxation and entrepreneurship. Bearing in mind the difference between unproductive and productive entrepreneurship, the positive effects seem mainly to encourage unproductive (or destructive) entrepreneurship and non-entrepreneurial selfemployment. Productive entrepreneurship has little to do with people who start their own ventures to avoid paying higher taxes. Rather, this effect likely reduces opportunities for legitimate and productive entrepreneurship. ${ }^{142}$

As the theoretical models give ambiguous results, we must look to empirical research to determine which is the dominant effect. However, empirical findings are still ambiguous in this respect. A great deal of empirical research analyzes taxation and entrepreneurship, but much lacks a satisfactory measure of entrepreneurship. Nearly all studies within the literature of empirical entrepreneurship struggle to define and quantify entrepreneurship. Self-employment levels are often used as a proxy

\footnotetext{
${ }^{137}$ Henrekson and Johansson (2009).

${ }^{138}$ This argument was first put forward by Domar and Musgrave (1944).

${ }^{139}$ A recent discussion of this effect is Cullen and Gordon (2007). It is noteworthy that in practice no tax system has full loss offset.

${ }^{140}$ Gentry and Hubbard (2000).

${ }^{141}$ Audrestch et al. (2002, p. 46).

${ }^{142}$ Audrestch et al. (2002, p. 46).
} 
because they are readily available and of relatively good quality over time and across countries, but this is a crude measure of entrepreneurship (as discussed in section 2). As a consequence, empirical results must be interpreted with caution. Taxation's positive or negative effect on self-employment levels does not indicate the same effect on truly entrepreneurial activity in general or productive entrepreneurial activity in particular.

The empirical results conflict at first glance, as both negative, positive and no effects are found. ${ }^{143}$ Parker (1996) and Schuetze (2000) find a positive effect (i.e., higher tax rate increases entrepreneurial activity), for example, whereas Moore (2004) observes a negative effect. Many studies also find no or only negligible effects from taxation (e.g., Stenkula 2009). OECD (2007) concludes that no simple relationship between low tax rates and the level of entrepreneurship can be established. Given the complexity of the tax code in a typical OECD country, the incentive effects of the tax code on entrepreneurial behavior are highly complex. A more detailed examination of the research illustrates that the average tax rate likely has a positive effect whereas the marginal tax rate likely has a negative effect. ${ }^{144}$ As stated earlier, a higher tax progression may also deter entrepreneurial activities. ${ }^{145}$

Many studies within this field often analyze the effect of one specific tax, like the tax on earned income, or use an overall aggregate tax measure, like taxes as a share of GDP. But what one should really analyze is taxes on entrepreneurial income. In practice, no specific tax on income from entrepreneurial effort exists. From a tax perspective, entrepreneurial income can be taxed in many different forms, including labor income, business income, current capital income (dividends and interest), or capital gains. These taxes may affect entrepreneurial activities in different ways. A thorough analysis of the effects of taxation on entrepreneurship must disentangle these effects.

To begin with, entrepreneurs can often choose their business form and its associated taxation. Income from labor and unincorporated businesses (business income) are often taxed in the same way - the sum of labor income and business

\footnotetext{
${ }^{143}$ For a general overview of the research until 2003, see Schuetze and Bruce (2004).

${ }^{144}$ See, e.g., Robson and Wren (1999).

${ }^{145}$ Gentry and Hubbard (2000).
} 
income is normally called earned income. As long as tax rates from earned income are higher than corporate tax rates (as is typically the case) and new ventures experience tax-deductible losses in the beginning (as tends to be the case), entrepreneurs will generally choose to start a new business as an unincorporated business. When the company is profitable at a later stage, the entrepreneur may want to incorporate the business. As a result of these differences, an increase of the earned income tax rate relative to the corporate income tax rate may actually encourage new ventures. ${ }^{146} \mathrm{~A}$ high tax on earned income makes the initial loss of a new venture less burdensome. (As discussed above, it may also be easier to avoid taxes as an entrepreneur in small or new businesses.)

However, income from entrepreneurial effort may be taxed as earned income to a larger extent than described above. First, the tax code may restrict the extent income accrued from closely held incorporated companies may be taxed as first corporate and then capital income at the personal level. ${ }^{147}$ Second, a great deal of the entrepreneurial function is carried out by employees without an ownership stake in the firm, for whom the earned income tax schedule is always applicable. For these categories, a high tax on earned income may have negative incentive effects.

High labor tax rates may also impede the emergence of a large, efficient service sector. Many activities within the household service sector are labor intensive tasks that can also be performed by unpaid household members themselves. High labor tax rates make it difficult to compete successfully with unpaid household production; consequently, commercial exploitation and entrepreneurial business development occur less often. ${ }^{148}$

Payroll taxes are normally included in discussions of labor taxation. High payroll taxes deter entrepreneurs from hiring employees if wage costs are too high (if the incidence of the payroll tax is on the employer/entrepreneur) or the net wage too low (if the incidence of the payroll tax is on the employee), or a combination of these two effects (if part of the incidence is on the employer and part on the employee).

\footnotetext{
${ }^{146}$ Kauffman Foundation (2007), and Cullen and Gordon (2007).

${ }^{147}$ This is true for Sweden, where the so-called 3:12 rules restrict how much of profits from closely held firms that can be taxed as dividends and not as earned income by the owners. See Agell et al. (1998), and Davis and Henrekson (2010).

${ }^{148}$ Henrekson and Johansson (2009).
} 
High payroll taxes could also discourage development within the service sector in the same way as the regular labor income tax.

Turning to capital and corporate taxation, a high tax rate on business profits discourages equity financing and spurs debt financing. To the extent that debt financing is less costly and more available for larger firms, high corporate tax rates coupled with tax-deductible interest payments disadvantage smaller firms and potential entrepreneurs. ${ }^{149}$ Taxing corporate profits also reduces the amount of retained earning that can be used to expand the existing venture. Research has shown that taxing profits in small firms often leads to lower growth rates. ${ }^{150} \mathrm{~A}$ higher tax rate on dividends encourages the reliance on retained earnings for financing expansion. This punishes new ventures, locks in retained earnings, and traps capital in incumbent firms. This could reduce the flow of capital into the most promising projects, as it favors projects in incumbent ventures. ${ }^{151}$

Most of the economic return from successful high-impact entrepreneurial firms comes as steeply increased stock market value rather than as dividends or large interest payments to the owners. As a result, the taxation of capital gains on stock holdings greatly affects the incentives for potential high-impact entrepreneurs. ${ }^{152}$ Successful entrepreneurs are also highly sensitive to wealth, property, and inheritance taxes. ${ }^{153}$ Certain assets are exempted from taxation in many countries, such as corporate wealth or pension savings, and the imputed value used as the basis for assessments is often based on arbitrary calculation rules. These rules may spur (like corporate wealth exemption) or discourage (like pension savings exemption) investments in entrepreneurial activities.

Stock options can be used to encourage and reward individuals who supply key competencies to a firm. In ideal circumstances, this would provide incentives that closely mimic direct ownership. This is most important for entrepreneurs in certain industries in which options are an effective response to agency problems.

\footnotetext{
${ }^{149}$ Henrekson (2007).

${ }^{150}$ Michaelas et al. (1999).

${ }^{151}$ Cf. Audretsch et al. (2002, p. 46).

${ }^{152}$ Henrekson and Johansson (2009). High corporate and capital gains taxation may also discourage the venture capital industry (Da Rin et al. 2006). See, however, Holtz-Eakin (2000, p. 288) for a critical discussion and calculation of the importance of capital gains taxation.

${ }^{153}$ See Rosen (2005) for an overview.
} 
The efficiency of stock options greatly depends on the tax code. If gains on stock options are taxed as wage income, some of the incentive effect is lost. This becomes particularly true if the gains are subject to (uncapped) social security contributions and if the marginal tax rate on wage income is high.

The situation changes dramatically if an employee with stock options can defer the tax liability to when the stocks are eventually sold. The effectiveness is reinforced further if the employee suffers no tax consequences upon the granting or the exercise of the option and if the employee is taxed at a low capital gains rate when the acquired stock is sold. The US changed the tax code in the early 1980s along these lines, paving the way for a wave of entrepreneurial ventures in Silicon Valley and elsewhere. ${ }^{154}$

In order to calculate the total effect of taxation, one must consider corporate taxation's specific rules for depreciation and valuation and the taxation of interest income, dividends, capital gains, and wealth. The effective total tax rates also depend on ownership category. ${ }^{155}$ In many developed countries, business ownership positions held directly by individuals and families have been taxed much more heavily than other ownership categories. The wave of tax reforms that swept the OECD in the 1980s smoothed over many of these differences. ${ }^{156}$ Those that still persist, however, spur an endogenous response in the ownership structure of the business sector towards the tax-favored owner categories. ${ }^{157}$ If individual stock holdings are disfavored relative to institutional holdings and institutions are less willing to invest in small and new entrepreneurial projects, entrepreneurial activity could be hampered. ${ }^{158}$

Finally, we must stress the importance of looking at the whole picture. Taxing citizens in an economy has several purposes, like financing public and merit goods, redistributing incomes, or controlling aggregate demand. A tax system should be efficient, transparent, and equitable. Policymakers should take all these aspects into consideration when designing the tax system - entrepreneurial effects are just one of

\footnotetext{
${ }^{154}$ Misher (1984), and Gompers and Lerner (2001).

155 These kinds of highly complicated estimates have been made for a number of countries using the methodology developed by King and Fullerton (1984).

${ }^{156}$ Jorgenson and Landau (1993).

${ }^{157}$ Rydqvist et al. (2009).

${ }^{158}$ Henrekson and Johansson (2009).
} 
many relevant aspects. ${ }^{159}$ Nevertheless, it is important to understand and consider the effect of taxes on entrepreneurial activity when designing and reforming a tax system. The design of a tax system may otherwise dampen entrepreneurial activity in the economy.

\subsection{Disincentives for unproductive entrepreneurship}

If institutions are such that it is beneficial for individuals to spend entrepreneurial effort on circumventing them, individuals will do so rather than benefiting from given institutions to reduce uncertainty and enhance contracts and product quality. In this case, corruption and predatory activities prevail over socially productive entrepreneurship. As discussed in section 4.2, the institutional framework must offer rewards to productive entrepreneurship. Moreover, the institutional framework should also weaken or ideally eliminate incentives for unproductive or destructive entrepreneurial activities.

A complex and ill-conceived tax system forces entrepreneurs to waste time and effort on tax issues, while a tax system with high tax rates increases the incentive to evade taxes. Entry barriers and high regulatory burdens can have the same negative effect.

\subsubsection{Bankruptcy law}

If the economy is to evolve and develop, unsuccessful and unproductive entrepreneurial ventures must close down so that their resources can be redirected to more productive uses. The institutional framework must hence make it easy to close down or reconstruct ventures. ${ }^{160}$

However, all failed projects should not be considered a waste of resources, as discussed earlier. Bankruptcies themselves are not unproductive (or destructive) entrepreneurship. Failed firms can create value for the economy as their very failure gives information to other agents; moreover, the knowledge generated/created by

\footnotetext{
${ }^{159}$ Cf. Acs and Szerb (2007).

${ }^{160}$ Audretsch et al. (2002), and OECD (1998).
} 
these firms can often be used by other firms. Restructuring a failed venture with new management may also result in improvements, for example. Knowledge from failed projects and ideas often can underlie the success of other ventures. ${ }^{161}$ The restriction or delay of this process by stringent bankruptcy regulation harms knowledge generation and development.

From an individual point of view, stringent bankruptcy laws discourage potential entrepreneurs because they increase the perceived cost of starting a business. A new business can always fail. As business formation, selection, and destruction often include a positive information and knowledge externality that the potential entrepreneur does not consider when starting a business, relatively generous bankruptcy laws seem reasonable. Examples include discharge clauses, postponement of debts, and the possibility of restructuring. Discharge clauses allow the debtor to cancel some debt, although its use varies from country to country. On the other hand, overly generous bankruptcy laws encourage exploitation and destructive entrepreneurship and may directly damage creditors while indirectly harming the rest of the community. ${ }^{162}$

Non-financial effects cause additional concerns. Psychological costs often accompany bankruptcies, and many countries exhibit negative public attitudes towards business failures. ${ }^{163}$ This stigma may discourage people from entrepreneurial activities despite good chances to succeed and prosper economically. Some countries like the United States, however, look more favorably upon failed business projects. ${ }^{164}$

Business culture must also give failed entrepreneurs a "second chance" and allow them to start anew. These entrepreneurs have often accumulated valuable experience and business networks that increase their probability of success in the future. Empirical research also shows that so-called habitual or serial entrepreneurs

\footnotetext{
${ }^{161}$ Gilbert et al. (2004), and Holbrook et al. (2000). Armour and Cummings (2005) show that the harshness of the bankruptcy law has a statistically and economically significant negative effect on selfemployment levels.

162 Audretsch et al. (2002), and OECD (1998).

${ }^{163}$ EU (2008), and OECD (1998). A survey has, e.g., shown that 47 percent of the Europeans would be reluctant to order from a business owned by somebody who has previously filed for bankruptcy. This will hardly facilitate entrepreneurial activities for re-starters. The average time to complete a bankruptcy varies also considerable within EU, from 4 months to 9 years (EU 2008).

${ }^{164}$ Audretsch et al. (2002).
} 
are more successful. ${ }^{165}$ Great business potential stems thus from re-starters, but cultural differences and institutions influence failed entrepreneurs' willingness to try new projects.

\subsection{Incentives to keep the winners on their toes}

The formation of successful ventures is necessary for economic progress-yet it is far from sufficient. Initial success can become stagnation in later stages. There is no guarantee that entrepreneurial ventures will continue to innovate and successfully evolve. Many large companies use their power and financial strength to protect themselves from competitors, thereby thwarting the entrepreneurial spirit found both within the firm and among potential competitors. The institutional framework should therefore foster an entrepreneurial economy that compels the old "winners" to continue to perform. ${ }^{166}$

To this end, public policy has traditionally constrained "big business" in order to ensure that large companies do not abuse their market power. This is often an illconceived approach, frequently involving lengthy legal processes with unpredictable outcomes. Alternatively, the government could attack the problem from the other direction: stimulate new and small businesses (or foreign firms), instead of trying to punish and restrain large companies. ${ }^{167}$

\subsubsection{Intellectual property rights}

The intellectual property rights system is an interesting example of how a second-best solution bears far-reaching consequences for entrepreneurial activities. In principle, property rights should encourage innovation and entrepreneurs. Yet a difficult tradeoff in the legal system must be made, and finding the right balance can be problematic. On the one hand, it is important to protect entrepreneurial ideas and ensure that entrepreneurs have the opportunity to reap the benefits of their own entrepreneurial

\footnotetext{
${ }^{165}$ See Ucbasaran et al. (2008) for an overview of habitual entrepreneurs.

${ }^{166}$ See Baumol et al. (2007) for a further and more detailed discussion.

${ }^{167}$ Gilbert et al. (2004).
} 
activities and projects. On the other hand, such exclusive monopoly privileges render protectionist entrepreneurial initiatives and impede healthy competition.

If protection is overly strong - if its time frame is too long or is too easy to obtain (including inventions which are not truly novel) — the initial entrepreneur will be able to extract excessive monopoly rents. This will definitely not keep winners "on their toes"; the economy could become less competitive and less innovative in response. Yet, if protection is too weak, or if it can be circumvented too easily (through unproductive or destructive entrepreneurship), there is no incentive to introduce innovations in the first place. ${ }^{168}$

In recent years, the protection of intellectual property has been strengthened in ways that increase both the cost and risk associated with innovative activity. Numerous studies claim that intellectual property rights protection laws have become too protective, notably in the US. ${ }^{169}$ This excessive protection could impede productive entrepreneurship, but it also spurs evasive and unproductive entrepreneurship to circumvent and to exploit the excessive protection of intellectual property. The system then functions as a tax on innovation, in that both the risk and the expected expense associated with innovative activity rises sharply.

\subsubsection{Trade and regulation}

Policies that inhibit new entry and subsidize specific companies or industries clearly cause stagnation. Willingness to engage in risky entrepreneurial projects declines sharply in an economy lacking the threat of new competitors. Sheltering domestic firms from foreign competition dampens innovative activity in already developed economies.

However, a dominant, formerly successful firm in a market will not necessarily stop innovating. In a contestable market with no (or low) entry and exit

\footnotetext{
${ }^{168}$ Baumol et al. (2007), Kauffman Foundation (2007), and Acs and Szerb (2007). See Merrill et al. (2004) for an in-depth discussion.

${ }^{169}$ Jaffee and Lerner (2004). In the US, the United States Patent and Trademark Office (USPTO) is overburdened as it is too easy to get a patent; the special court in the US that deals with these issues (CAFC) has over time given greater protection to patent claimants (Kauffman Foundation 2007, p. 24).
} 
costs, the incentive to innovate may still be present. ${ }^{170}$ Low entry barriers, as discussed in section 4.1.1, then become crucial.

Even with low entry barriers, the number of firms in the market may be limited by the extent of the domestic market; in combination with economies of scale (and scope) and high sunk entry costs, the interplay pressures incumbents too little. In this case, international trade can stimulate the competition and contestability of the market as incumbent firms are exposed to international competitors. The market expands at the same time as foreign firms may already have incurred the necessary sunk costs. As a result, international competition can spur the domestic innovation process as long as the domestic economy is not sheltered from competition from foreign firms.

\section{Summary and conclusions}

The successful commercialization of an innovation requires a chain of agents that work together in order to develop a high-impact firm. Entrepreneurship is arguably the most important. In this chapter, we have examined policy areas and policy measures that foster a favorable environment for high-impact entrepreneurship.

Our analysis emphasizes the complementary character of institutions. If policymakers would like to improve conditions for high-impact entrepreneurship, a wide array of complementary institutional reforms should be adopted.

We have identified and categorized institutions important for productive entrepreneurship in general and high-impact entrepreneurship in particular, based on Baumol et al.'s (2007) four tenets of an entrepreneurial economy. According to Baumol et al. (2007), a successful entrepreneurial economy is characterized by (1) ease of starting and expanding a business; (2) rewards for productive entrepreneurial activity; (3) disincentives for unproductive activity; and (4) incentives to keep the winners on their toes.

Based on the above classification, we have discussed eleven public policy areas, including seemingly disparate areas such as the design of the social security system

\footnotetext{
${ }^{170}$ Cf. Baumol et al. (1982).
} 
and the extent of intellectual property rights. We identify a number of distortions within these policy areas that could disfavor productive and high-impact entrepreneurship. In particular, we have analyzed the importance of regulatory entry and growth barriers, labor market regulation, liquidity constraints, and tax policy in depth.

This chapter discusses entrepreneurship policy rather than SME policy. Entrepreneurship policy aims to support socially productive entrepreneurial activity, independent of business form. SME policy is a much narrower concept and includes specific support to encourage distinct groups or firms, such as SMEs and the selfemployed. It often involves the creation of specific government agencies as well as targeted subsidies. Part of industrial policy in developed countries can certainly be characterized as SME policy during the 1980s and 1990s.

\section{Table 2 about here}

Table 2 summarizes the issues discussed in this chapter and their ensuing policy conclusions. Under each policy area, we list public policies that contribute to an "entrepreneurial economy" and a "managed economy". It should be stressed that many institutions and policy measures reinforce the effects pushing the system in either the managed or entrepreneurial direction.

Finally, we must keep in mind that each country has its own unique characteristics that cannot be easily replicated or imitated by public policies. Therefore, we abstain from ranking policies or identifying the "best" policy combination. Such identification would require in-depth country analyses far beyond the scope and purpose of this book chapter.

\section{References}

Acemoglu, Daron, and Johnson, Simon (2005). "Unbundling Institutions." Journal of Political Economy 113(5): 947-997.

Acs, Zoltan J. (2008) "Foundations of High Impact Entrepreneurship." Foundations and Trends in Entrepreneurship 4(6): 535-620.

Acs, Zoltan J., Braunerhjelm, Pontus, and Audretsch, David B. (2009). "The Knowledge Spillover Theory of Entrepreneurship.” Small Business Economics 32(1): 15-30. 
Acs, Zoltan J., and Szerb, Laszlo (2007). "Entrepreneurship, Economic Growth and Public Policy.” Small Business Economics 28(2-3): 109-122.

Adema, Willem (2001). "Net Social Expenditure: $2^{\text {nd }}$ Edition." OECD Labor Market and Social Policy Occasional Papers No. 52. Paris: OECD.

Adema, Willem, and Ladaique, Maxime (2005). "Net Social Expenditure, 2005 Edition: More Comprehensive Measures of Social Support." OECD Social, Employment and Migration Working Papers No. 29. Paris: OECD.

Agell, Jonas, Englund, Peter, and Södersten, Jan (1998). Incentives and Redistribution in the Welfare State - The Swedish Tax Reform. London: Macmillan.

Andersen, Torben M. (2008). "The Scandinavian Model - Prospects and Challenges." International Tax and Public Finance 15(1): 45-66.

Armour, John and Cumming, Douglas J. (2005). "Bankruptcy Law and Entrepreneurship." American Law \& Economic Review 10(2): 303-350.

Audretsch, David B., Grilo, Isabel, and Thurik, A. Roy (2007). "Explaining Entrepreneurship and the Role of Policy: A Framework." In Audretsch, David B., Grilo, Isabel and Thurik, A. Roy (eds.) Handbook of Entrepreneurship Policy. Cheltenham: Edward Elgar.

Audrestch, David B., Thurik, Roy, Verheul, Ingrid, and Wennekers, Sander (eds.) (2002). Entrepreneurship: Determinants and Policy in a European-US Comparison. Boston, Dodrecht and London: Kluwer.

Bamford, Charles E., Dean, Thomas J., and Douglas, Thomas J. (2004). "The Temporal Nature of Growth Determinants in New Bank Founding: Implications for New Venture Research Design." Journal of Business Venturing 19(6): 223-242.

Bandiera, Oriana (2003). "Land Reform, the Market for Protection, and the Origins of the Sicilian Mafia: Theory and Evidence." Journal of Law, Economics and Organization 19(1): 218-244.

Baumol, Willam J. (1990). "Entrepreneurship: Productive, Unproductive, Destructive.” Journal of Political Economy 98(5): 893-921.

Baumol, William J. (1993). "Health Care, Education and the Cost Disease: A Looming Crisis for Public Choice." Public Choice 77(1): 17-28.

Baumol, William J. (2002). The Free-Market Innovation Machine. Princeton and Oxford: Princeton University Press.

Baumol, William J., Litan, Robert E., and Schramm, Carl J. (2007). Good Capitalism, Bad Capitalism and the Economics of Growth and Prosperity. New Haven and London: Yale University Press.

Baumol, William J., Panzar, John C., and Willig, Robert D. (1982). Contestable Markets and the Theory of Industry Structure. New York: Harcourt Brace Jovanovich.

Berger, Allen N., and Udell, Gregory F. (1988). "The Economics of Small Business Finance: The Roles of Private Equity and Debt Markets in the Financial Growth Cycle." Journal of Banking and Finance 22(6-8): 613-673.

Bergström, Fredrik (2000). "Capital Subsidies and the Performance of Firms." Small Business Economics 13(3): 183-193.

Bergström, Fredrik, and Sandström, Mikael (2005). "School Vouchers in Practice: Competition Will not Hurt You." Journal of Public Economics 89(2-3): 351-380.

Bhidé, Amar (2008). The Venturesome Economy. Princeton and Oxford: Princeton University Press.

Birch, David L. (1979). The Job Generation Process. Cambridge, MA: MIT Program on Neighborhood and Regional Change.

Birch, David L. (2006). "What Have We Learned?" Foundations \& Trends in Entrepreneurship 2(3): 197-202.

Boettke, Peter J., and Coyne, Christopher J. (2003). "Entrepreneurship and Development: Cause or Consequence?" Advances in Austrian Economics 6: 67-88. 
Boettke, Peter J., and Coyne, Christopher J. (2009). "Context Matters: Institutions and Entrepreneurship." Foundations and Trends in Entrepreneurship 5(3): 135-209.

Borger J. C., Janssen, N. L .C. M., and van Noort, E. A. (2000). The Venture Capital Market for SMEs. An International Perspective. Zoetermeer: EIM Business and Policy Research.

Bottazzi Laura, and Da Rin, Marco (2002). "Venture Capital in Europe and the Financing of Innovative Companies." Economic Policy 17(34): 229-270.

Bowles, Samuel (1998). "Endogenous Preferences: The Cultural Consequences of Markets and Other Economic Institutions." Journal of Economic Literature 36(1), 75-111.

Boyns, Nic, Cox, Mark, Spires, Rod, and Hughes, Alan (2003). Research into the Enterprise Investment Scheme and Venture Capital Trusts. PACEC Report for Inland Revenue.

Bygrave, William D., and Hunt, Stephen A. (2004). Global Entrepreneurship Monitor (GEM) 2004 Financing Report. Wellesley and London: Babson College and London Business School.

Caballero, Ricardo (2007). Specificity and the Macroeconomics of Restructuring. Cambridge, MA: MIT Press.

Capelleras, Joan-Lluis, Mole, Kevin F., Greene, Francis J., and Storey, David J. (2008). "Do More Heavily Regulated Economies Have Poorer Performing New Ventures: Evidence from Britain and Spain?" Journal of International Business Studies 39(4): 688-704

Carlsson, Bo (2009). "Entrepreneurship and Public Policy in Emerging Clusters." SNEE Working Paper, May 2009.

Crain, W. Mark, and Hopkins, Thomas D. (2001). "The Impact of Regulatory Costs on Small Firms." Report prepared for the Office of Advocacy, US Small Business Administration.

Cullen, Julie Berry, and Gordon, Roger H. (2007). "Taxes and Entrepreneurial Risk-taking: Theory and Evidence for the U.S." Journal of Public Economics 91(7-8), 1479-1505.

Cumming, Douglas J., and Macintosh, Jeffrey G. (2006). "Crowding Out Private Equity: Canadian Evidence." Journal of Business Venturing 21(5), 569-609.

Da Rin, Marco, Nicodano, Giovanna, and Sembenelli, Alessandro (2006). "Public Policy and the Creation of Active Venture Capital Markets." Journal of Public Economics 90(8-9): $1699-1723$.

Davis, Steven J., and Henrekson, Magnus (2010). "Economic Performance and Work Activity in Sweden after the Crisis of the Early 1990s." In Freeman, Richard M., Swedenborg, Birgitta, and Topel, Robert (eds.) Reforming the Welfare State - Recovery and Beyond in Sweden. Chicago: University of Chicago Press.

de Meza, David (2002). “Overlending?” Economic Journal 112(477): F17-F31.

de Meza, David and Southey, Clive (1996). "The Borrower's Curse. Optimism, Finance and Entrepreneurship.” Economic Journal 106(435): 375-386.

de Soto, Hernando (1989). The Other Path. New York: Basic Books.

de Soto, Hernando (2000). The Mystery of Capital: Why Capitalism Triumphs in the West and Fails Everywhere else. New York: Basic Books.

Dean, Thomas J., and Meyer, G. Dale (1996). "Industry Environments and New Venture Formations in U.S. Manufacturing: A Conceptual and Empirical Analysis of Demand Determinants." Journal of Business Venturing 11(2): 107-132.

Delmar, Frédéric, Wennberg, Karl, Wiklund, Johan, and Sjöberg, Karin (2005). "SelfEmployment among the Swedish Science and Technology Labor Force: The Evolution of Firms between 1990 and 2000." Report A2005:001. Östersund: Swedish Institute for Growth Policy Studies.

Desai, Mihir, Gompers, Paul A., and Lerner, Josh. (2003). "Institutions, Capital Constraints and Entrepreneurial Firm Dynamics: Evidence from Europe.” NBER Working Paper No. 10165.

Djankov, Simeon, La Porta, Rafael, Lopez-de-Silanes, Florencio, and Shleifer, Andrei (2002). "The Regulation of Entry." Quarterly Journal of Economics 117(1), 1-37. 
Domar, Evsey and Musgrave, Richard A. (1944). "Proportional Income Taxation and Risk Sharing." Quarterly Journal of Economics 58(3): 388-422.

Douhan, Robin, and Henrekson, Magnus (2010). "Entrepreneurship and Second-Best Institutions: Going Beyond Baumol's Typology." Journal of Evolutionary Economics (in press).

Douhan, Robin, Norbäck, Pehr-Johan, and Persson, Lars (2009). "Entrepreneurship Policy and Globalization." IFN Working Paper No. 807.

Drucker, Peter F. (1976). The Unseen Revolution: How Pension Fund Socialism Came to America. London: Heinemann.

Engström, Per, and Holmlund, Bertil (2009). "Tax Evasion and Self-Employment in a HighTax Country: Evidence from Sweden." Applied Economics 41(19): 2419-2430.

EU (2002). "More Research for Europe: Towards 3\% of GDP." COMM 2002(499). Brussels: European Commission.

EU (2007). "Models to Reduce the Disproportionate Regulatory Burden on SMEs." Enterprise and Industry Directorate-General. Report of the Expert Group. Brussels: European Commission.

EU (2008). “Think Small First. A Small Business Act for Europe.” DG Enterprise. Brussels: European Commission.

Fazzari, Steven M., Hubbard, R. Glenn, and Petersen, Bruce C. (1988). "Financing Constraints and Corporate Investment." Brookings Papers on Economic Activity 1: 141195.

Fogel, Robert W. (1999). "Catching Up with the Economy." American Economic Review $89(1), 1-21$.

Friedman, Milton (1962). Capitalism and Freedom. Chicago: University of Chicago Press.

Gentry, William M., and Hubbard, R. Glenn (2000). "Tax Policy and Entrepreneurial Entry." American Economic Review 90(2): 283-287.

Gilbert, Brett Anitra, Audretsch, David B., and McDougall, Patricia P. (2004). "The Emergence of Entrepreneurship Policy." Small Business Economics 22(3-4): 313-323.

Gompers, Paul A. and Lerner, Josh (1999). "What Drives Venture Capital Funding?" NBER Working Paper No. 6906.

Gompers, Paul A., and Lerner, Josh (2001). The Money of Invention: How Venture Capital Creates New Wealth. Cambridge, MA: Harvard University Press.

Gompers, Paul A., and Lerner, Josh (2004). The Venture Capital Cycle, 2nd edition. Cambridge: MIT Press.

Gompers, Paul A., Lerner, Josh, and Kovner, Anna R. (2009). "Specialization and Success: Evidence from Venture Capital.” Journal of Economics \& Management Strategy 18(3): 817-844.

Haggarty, Luke, Rada, Kristtian, and Dohm, Edward (2006). "Cutting Red Tape Simplifying Regulation at the Municipal Level in Latin America: Lessons from IFC's Experience in Peru and Nicaragua." International Finance Corporation.

Hart, David M. (2003). "Entrepreneurship Policy: What it is and Where it Came From." In Hart, David M. (ed.) The Emergence of Entrepreneurship Policy: Governance, Start-Ups, and Growth in the U.S. Knowledge Economy. Cambridge: Cambridge University Press.

Hayward, Mathew L. A., Shepherd, Dean A., and Griffin, Dale (2006). "A Hubris Theory of Entrepreneurship." Management Science 52(2): 160-172.

Henrekson, Magnus (2007). "Entrepreneurship and Institutions." Comparative Labor Law \& Policy Journal 28(3): 717-742.

Henrekson, Magnus, and Johansson, Dan (2009). "Competencies and Institutions Fostering High-growth Firms.” Foundations and Trends in Entrepreneurship 5(1): 1-82.

Henrekson, Magnus, and Johansson, Dan (2010). "Gazelles as Job Creators - A Survey and Interpretation of the Evidence." Small Business Economics (in press). 
Henrekson, Magnus, and Rosenberg, Nathan. (2001). "Designing Efficient Institutions for Science-Based Entrepreneurship: Lessons from the US and Sweden." Journal of Technology Transfer 26(3): 207-231.

Henrekson, Magnus, and Sanandaji, Tino (2010). "The Interaction between Entrepreneurship and Institutions." IFN Working Paper No. 830.

Ho, Yuen-Ping, and Wong, Poh-Kam (2007). "Financing, Regulatory Costs and Entrepreneurial Propensity.” Small Business Economics 28(2-3): 187-204.

Hoffman, Anders N. (2007). "A Rough Guide to Entrepreneurship Policy." In Audretsch, David B., Grilo, Isabel and Thurik, A. Roy (eds.) Handbook of Entrepreneurship Policy. Cheltenham: Edward Elgar.

Holbrook, Daniel, Cohen, Wesley M., Hounshell, David A., and Klepper, Steven (2000). "The Nature, Sources, and Consequences of Firm Differences in the Early History of the Semiconductor Industry." Strategic Management Journal 21(10-11): 1017-1041.

Holcombe, Randall G. (2007). Entrepreneurship and Economic Progress. New York: Routledge.

Holtz-Eakin, Douglas (2000). "Public Policy Toward Entrepreneurship.” Small Business Economics 15(4): 283-291.

Hurst, Erik, and Lusardi, Annamaria (2004). "Liquidity Constraints, Household Wealth, and Entrepreneurship." Journal of Political Economy 112(2): 319-347.

Ilmakunnas, Pekka, and Kanniainen, Vesa (2001). "Entrepreneurship, Economic Risks and Risk Insurance in the Welfare State: Results with OECD Data 1978-93." German Economic Review 2(3): 195-218.

Iversen, Jens, Jørgensen, Rasmus, and Malcow-Møller, Nikolaj (2008). ’Defining and Measuring Entrepreneurship." Foundations and Trends in Entrepreneurship 4(1): 1-63.

Jaffee, Adam B. and Lerner, Josh (2004). Innovation and Its Discontents: How Our Broken Patent System Is Endangering Innovation and Progress, and What to Do about It? Princeton, NJ: Princeton University Press.

Jansson, Jan Owen (2006). The Economics of Services: Development and Policy. Cheltenham: Edward Elgar.

Jensen, Paul H. and Stonecash, Robin E. (2005). "Incentives and the Efficiency of Public Sector-Outsourcing Contracts." Journal of Economic Surveys 19(5): 767-787.

Johansson, Dan (2010). "The Theory of the Experimentally Organized Economy and Competence Blocs: An Introduction." Journal of Evolutionary Economics 20(2): 185201.

Johnson, Simon, McMillan, John, and Woodruff, Christopher (2002). "Property Rights and Finance." American Economic Review 92(5), 1335-1356.

Jorgenson, Dale W., and Landau, Ralph (eds.) (1993). Tax Reform and the Cost of Capital: An International Comparison. Washington, DC: The Brookings Institute.

Kauermann, Göran, Tutz, Gerhard, and Brüdel, Josef (2005). "The Survival of Newly Founded Firms: A Case-study into Varying-coefficient Models." Journal of the Royal Statistical Society Series A-Statistics in Society 168(1): 145-158.

Kauffman Foundation (2007). "On the Road to an Entrepreneurial Economy: A Research and Policy Guide." Ewing Marion Kauffman Foundation Working Paper, July 2007.

Kauffman Foundation (2008). "Entrepreneurship Summit. Executive Summary.” Ewing Marion Kauffman Foundation and the International Economic Development Council Working Paper, September 2008.

Kesselman, Jonathan R. (1989). "Income Tax Evasion: An Intersectoral Analysis." Journal of Public Economics 38(2): 137-182.

Keuschnigg, Christian, and Nielsen, Søren (2004a). "Taxation and Venture Capital Backed Entrepreneurship." International Tax and Public Finance 11(4): 369-390. 
Keuschnigg, Christian, and Nielsen, Søren (2004b). "Start-ups, Venture Capitalists, and the Capital Gains Tax.” Journal of Public Economics 88(5): 1011-1042.

King, Mervyn A., and Fullerton, Don (eds.) (1984). The Taxation of Income from Capita: A Comparative Study of the United States, the United Kingdom, Sweden and West Germany. Chicago: University of Chicago Press.

Klapper, Leora F., Laeven, Luc A., and Rajan, Raghuram G. (2004). "Business Environment and Firm Entry: Evidence from International Data." NBER Working Paper No. 10380.

Kleiner, Morris M. (2006). Licensing Occupations: Ensuring Quality or Restricting Competition? Kalamazoo, MI: W.E. Upjohn Institute.

Klinger, Bailey, and Lederman, Daniel (2006). "Diversification, Innovation and Imitation inside the Global Technological Frontier." World Bank Policy Research Department Working Paper No. 3872.

Koellinger, Philipp, and Minniti, Maria (2009). "Unemployment benefits crowd out entrepreneurial activity." Economics Letters 103(2): 96-98.

Lazerson, Mark H., and Lorenzoni, Gianni (1999). "The Firms That Feed Industrial Districts: A Return to the Italian Source." Industrial and Corporate Change 8(2): 235-266.

Libecap, Gary (1993). "Entrepreneurship, Property Rights and Economic Growth.” In Advances in the Study of Entrepreneurship, Innovation and Economic Growth: A Research Annual. Vol 6. Greenwich, CT: JAI Press.

Lindelöf, Peter, and Löfsten, Hans (2003). "Science Park Location and New Technology Based Firms in Sweden - Implications for Strategy and Performance." Small Business Economics 20(3): 245-258.

Long, James E. (1982). “The Income Tax and Self-Employment." National Tax Journal 35(1): 31-42.

Lundström, Anders, and Stevenson, Lois (2002). On the Road to Entrepreneurship Policy. Volume 1 of the Entrepreneurship Policy for the Future Series. Örebro: FSF.

Lundström, Anders, and Stevenson, Lois (2005). Entrepreneurship Policy: Theory and Practices. ISEN International Studies in Entrepreneurship. New York: Springer.

Mason, Colin M. (2006). "Informal Sources of Venture Finance.” In Parker, Simon C. (ed.) The Life Cycle of Entrepreneurial Ventures. Volume 3. International Handbook on Entrepreneurship. New York: Springer.

Meager, Nigel, Bates, Peter, and Cowling, Marc (2003). "An Evaluation of Business Start-up Support for Young People.” National Institute Economic Review 186(1): 59-72.

Merrill, Stephen A., Levin, Richard C., and Myers, Mark B. (2004). A Patent System for the $21^{\text {st }}$ Century. Washington, DC: National Academic Press.

Michaelas, Nicos, Chittenden, Francis, and Poutziouris, Panikkos (1999). "Financial Policy and Capital Structure Choice in UK SMEs: Empirical Evidence from Company Panel Data.” Small Business Economics 12(2): 113-130.

Milhaupt, Curtis J., and Mark D. West (2000). "The Dark Side of Private Ordering: An Institutional and Empirical Analysis of Organized Crime." University of Chicago Law Review 67(1): 41-98.

Misher, Norman (1984). "Tax Consequences of Exercising An Incentive Stock Option with Stock of the Granting Corporation." The Tax Executive, July, 357-363.

Moore, Kevin B. (2004). "The Effects of the 1986 and 1993 Tax Reforms on SelfEmployment." FEDS Working Paper No. 2004-05.

Murphy, Kevin M., Shleifer, Andrei, and Vishny, Robert W. (1991). "The Allocation of Talent: Implications for Growth.” Quarterly Journal of Economics 106(2): 503-530.

Nickell, Stephen (1997). "Unemployment and Labor Market Rigidities: Europe versus North America." Journal of Economic Perspectives 11(3): 55-74.

Niehof, Jacques (1999). "Barriers for Hiring Personnel.” Research Report 9807/E. Zoetermeer: EIM Business and Policy Research. 
Nijsen, André F. M. (2000). "Phases in the Recognition of Information Transfer Compliance Costs." In Brauchlin, Emil and Pichler, J. Hans (eds.) Unternehmer und

Unternehmensperspektiven für Klein- und Mittelunternehmen. Berlin and S:t Gallen:

Duncker and Humblot.

Norbäck, Per-Johan, and Persson, Lars (2009). "The Organization of the Innovation Industry: Entrepreneurs, Venture Capitalists, and Oligopolists." Journal of the European Economic Association 7(6): 1261-1290.

North, Douglass C., and Weingast, Barry R. (1989). "Constitutions and Commitment: Evolution of Institutions Governing Public Choice in Seventeenth Century England." Journal of Economic History 49(4): 803-832.

Nykvist, Jenny (2008). "Entrepreneurship and Liquidity Constraints: Evidence from Sweden." Scandinavian Journal of Economics 110(1): 23-43.

OECD (1994). "Employment Protection Regulation and Labor Market Performance." OECD Employment Outlook. Paris: OECD.

OECD (1998). Fostering Entrepreneurship, the OECD Jobs Strategy. Paris: OECD.

OECD (2000). OECD Employment Outlook. Paris: OECD.

OECD (2003). The Sources of Economic Growth in the OECD Countries. Paris: OECD.

OECD (2005). Small and Medium Enterprise and Entrepreneurship Outlook. Paris: OECD.

OECD (2007). OECD Framework for the Evaluation of SME and Entrepreneurship Policies and Programmes. Paris: OECD.

Orszag, Mike, and Snower, Dennis J. (1998). "Anatomy of Policy Complimentarities." Swedish Economic Policy Review 5(2): 303-343.

Parker, Simon C. (1996). "A Time-series Model of Self-employment under Uncertainty." Economica 63(251): 459-475.

Parker, Simon C. (2004). The Economics of Self-Employment and Entrepreneurship. Cambridge: Cambridge University Press.

Pelikan, Pavel (1988). "Can the Imperfect Innovation Systems of Capitalism be Outperformed?" In Dosi, Giovanni et al. (eds.) Technical Change and Economic Theory. London: Pinter.

Pestieau, Pierre, and Possen, Uri M. (1991). “Tax Evasion and Occupational Choice.” Journal of Public Economics 45(1): 107-125.

Pyke, Frank, Becattini, Giacomo, and Sengenberger, Werner (eds.) (1990). Industrial Districts and Inter-firm Cooperation in Italy. Geneva: IILS.

Reynolds, Paul D., Bygrave, William D., Autio, Erkko and Hay, Michael (2002). Global Entrepreneurship Monitor Executive Report 2002. Wellesley and London: Babson College and London Business School.

Robson, Martin T., and Wren, Colin (1999). "Marginal and Average Tax Rates and the Incentive for Self-Employment." Southern Economic Journal 65(4): 757-773.

Rodrik, Dani (2007). One Economics, Many Recipes: Globalization, Institutions, and Economic Growth. Princeton and Oxford: Princeton University Press.

Rodrik, Dani, Subramanian, Arvind, and Trebbi, Francesco (2004). "Institutions Rule: The Primacy of Institutions over Geography and Integration in Economic Development." Journal of Economic Growth 9(2), 131-165.

Rosen, Harvey S. (2005). "Entrepreneurship and Taxation: Empirical Evidence." In Kanniainen, Vesa and Keuschnigg, Christian (eds.) Venture Capital, Entrepreneurship and Public Policy. Cambridge, MA: MIT Press.

Rydqvist, Kristian, Spizman, Joshua, and Strebulaev, Ilya (2009). "The Evolution of Aggregate Stock Ownership: A Unified Explanation.” ECGI Finance Working Paper No. $263 / 2009$ 
Scarpetta, Stefano, Hemmings, Philip, Thierry, Tressel, and Jaujoon, Woo (2002).’The Role of Policy and Institutions for Productivity and Firm Dynamics: Evidence from the Micro and Industry Data." OECD Economic Department Working Paper No 329.

Schuetze, Herbert J. (2000). "Taxes, Economic Conditions and Recent Trends in Male SelfEmployment: Canada-U.S. Comparison.” Labour Economics 7(5): 507-544.

Schuetze, Herbert J., and Bruce, Donald (2004). "Tax Policy and Entrepreneurship." Swedish Economic Policy Review 11(2): 233-265.

Shane, Scott A. (2008). The Illusions of Entrepreneurship. New Haven and London: Yale University Press.

Shleifer, Andrei (1998). "State versus Private Ownership." Journal of Economic Perspectives 12(4): 133-150.

Siegel, Donald S., Wessner, Charles, Binks, Martin, and Lockett, Andy (2003). "Policies Promoting Innovation in Small Firms: Evidence from the U.S. and U.K." Small Business Economics 20(2): 121-127.

Skedinger, Per (2010). Employment Protection Legislation: Evolution, Effects, Winners and Losers. Cheltenham, UK and Northampton, MA: Edward Elgar.

Slemrod, Joel (1986). "Income Creation or Income Shifting? Behavioral Responses to the Tax Reform Act of 1986." American Economic Review 85(2): 175-180.

Smith, Vernon (2003). "Constructivist and Ecological Rationality in Economics." American Economic Review 93(3): 465-490.

Stenkula, Mikael (2009). "Taxation and Entrepreneurship in a Welfare State.” IFN Working Paper No. 800.

Storey, David J. (1994). Understanding the Small Business Sector. London and New York: Routledge.

Storey, David J. (2003). "Entrepreneurship, Small and Medium Sized Enterprises and Public Policies." In Acs, Zoltan J., and Audretsch, David B. (eds.) Handbook of Entrepreneurship Research. Boston, Dordrecht and London: Kluwer.

Svensson, Roger (2008). "Innovation Performance and Government Financing." Journal of Small Business and Entrepreneurship 21(1): 95-116.

Ucbasaran, Deniz, Alsos, Gry Agnete, Westhead, Paul, and Wright, Mike (2008). "Habitual Entrepreneurs." Foundations and Trends in Entrepreneurship 4(4): 309-450.

van Auken, Howard E. (1999). "Obstacles to Business Launch." Journal of Developmental Entrepreneurship 4(2): 175-187.

van Stel, André, Storey, David J., and Thurik, A Roy (2007). "The Effect of Business Regulations on Nascent and Young Business Entrepreneurship.” Small Business Economics 28 (2-3): 171-186.

van Stel, André, and Storey, David J. (2004). "The Link between Firm Births and Job Creation: Is there a Upas Tree Effect?” Regional Studies 38(8): 893-909.

Watson, Harry (1985). “Tax Evasion and Labor Markets.” Journal of Public Economics 27(2): 231-246.

World Bank (2005a). Doing Business 2005: Poor Nations Struggle to Reduce Red Tape for Business, Miss Large Growth Opportunities. Washington: Worldbank.

World Bank (2005b). World Development Report 2005: A Better Investment Climate for Everyone. Washington: World Bank. 
Table 1. Summary of policies and how they relate to Baumol et al.'s four tenets

\begin{tabular}{|c|c|c|c|c|}
\hline & $\begin{array}{l}\text { Ease of start- } \\
\text { ing and } \\
\text { expanding a } \\
\text { business }\end{array}$ & $\begin{array}{l}\text { Rewards for } \\
\text { productive } \\
\text { entrepreneurial } \\
\text { activity }\end{array}$ & $\begin{array}{l}\text { Disincentives } \\
\text { for unproduc- } \\
\text { tive activity }\end{array}$ & $\begin{array}{l}\text { Incentives to } \\
\text { keep winners } \\
\text { on their toes }\end{array}$ \\
\hline Section & 4.1 & 4.2 & 4.3 & 4.4 \\
\hline \multicolumn{5}{|l|}{ Policy } \\
\hline $\begin{array}{l}\text { Regulatory entry } \\
\text { and growth } \\
\text { barriers }\end{array}$ & $\mathrm{X}$ & & $(\mathrm{x})$ & $(\mathrm{x})$ \\
\hline $\begin{array}{l}\text { Liquidity and capital } \\
\text { constraints }\end{array}$ & $\mathrm{X}$ & & & \\
\hline Labor market & X & & & \\
\hline Social security & X & $(\mathrm{x})$ & & \\
\hline $\begin{array}{l}\text { R\&D, commer- } \\
\text { cialization \& know- } \\
\text { ledge spillover }\end{array}$ & $\mathrm{X}$ & $(\mathrm{x})$ & & $(\mathrm{x})$ \\
\hline Targeted support & $\mathrm{X}$ & & & $(\mathrm{x})$ \\
\hline Property rights & $(\mathrm{x})$ & $\mathrm{X}$ & & \\
\hline Taxation & $(\mathrm{x})$ & $\mathrm{X}$ & $(\mathrm{x})$ & \\
\hline Bankruptcy laws & $(\mathrm{x})$ & & $\mathrm{X}$ & \\
\hline $\begin{array}{l}\text { Intellectual property } \\
\text { rights }\end{array}$ & & (x) & & $\mathrm{X}$ \\
\hline Trade and regulation & $(\mathrm{x})$ & & & $X$ \\
\hline
\end{tabular}

Note: All public policies can be relevant for more than one of Baumol et al's four tenets. In that case the tenet which is deemed to be the most important is marked with an X, while other tenet/tenets of lesser relevance are marked with an (X). The respective policies will be discussed in the section seen as the most relevant. 
Table 2. Public policy supporting an entrepreneurial economy vs. a managed economy

\begin{tabular}{lll}
\hline Public policy & Managed economy & $\begin{array}{l}\text { Entrepreneurial } \\
\text { economy }\end{array}$ \\
\hline
\end{tabular}

Regulatory entry and growth barriers:

- Entry barriers

- Production of welfare services/merit goods

- Financing of welfare services/merit goods

- Profit-driven organizations
High Low

Government production Sizeable private production, contestability

Tax financing only Government ensures basic high quality supply, then private financing

Partly de facto prohibited Fully allowed in key areas facing income-elastic demand

\section{Liquidity and capital constraints:}

- Wealth formation

- Venture capital

Labor market:

- Labor security mandates

- Wage-setting arrangements
High levels of income redistribution and wealth $\operatorname{tax}$

Direct support

Tied to years of tenure Centralized and closely tied to formal criteria

\section{Social security:}

- Design

R\&D, commercialization and knowledge spillover:

- Focus

\section{Targeted support \\ Property rights}

Quantitative goals of input (spending on $\mathrm{R} \& \mathrm{D}$ )

Yes

Weak
Support private wealth formation

Indirect support

Portability of tenure rights

Decentralized and individualized

Portability of tenure rights
No quantitative goals, indirect support, enabling and general

No

Stable and secure 


\section{Taxation:}

- Earned income tax rate

High and progressive Low or moderate

- Capital income tax rate

High

Low

- Capital gains tax rate

High

Low

- Tax on stock options

High

Low

- Degree of tax neutrality across owner categories

Favor institutional owners over individuals

- Degree of neutrality across sources of finance

- Personal taxation of asset holdings

- Corporate tax rate

Favor debt over equity

Neutrality

Neutrality

Yes, in particular on equity

No, or exemption for equity holdings

High statutory rate, low Low or moderate statutory effective rate rate, effective rate equal to statutory rate, and neutral across types of firms and industries

\begin{tabular}{lll} 
Bankruptcy laws & Onerous and lengthy & $\begin{array}{l}\text { Generous, allow for a } \\
\text { "second chance" }\end{array}$ \\
Intellectual property rights & $\begin{array}{l}\text { Very strong, easily } \\
\text { obtained }\end{array}$ & $\begin{array}{l}\text { Balance inventors" } \\
\text { interests against need for } \\
\text { knowledge dissemination }\end{array}$ \\
Trade and regulation & $\begin{array}{l}\text { Protect national and } \\
\text { incumbent firms }\end{array}$ & Openness \\
\hline
\end{tabular}

